\title{
SARS-CoV-2 infection generates tissue-localized immunological memory in humans
}

\author{
Maya M.L. Poon, ${ }^{1,2 \dagger}$ Ksenia Rybkina, ${ }^{1+}$ Yu Kato, ${ }^{3+}$ Masaru Kubota, ${ }^{4}$ Rei Matsumoto, ${ }^{4}$ Nathaniel I. Bloom, ${ }^{3}$ Zeli \\ Zhang, ${ }^{3}$ Kathryn M. Hastie, ${ }^{3}$ Alba Grifoni, ${ }^{3}$ Daniela Weiskopf ${ }^{3}$ Steven B. Wells, ${ }^{5}$ Basak B. Ural, ${ }^{1}$ Nora Lam,,${ }^{1,6}$ \\ Peter A. Szabo, ${ }^{1}$ Pranay Dogra, ${ }^{1}$ Yoon S. Lee, ${ }^{1}$ Joshua I. Gray, ${ }^{1}$ Marissa C. Bradley, ${ }^{7}$ Maigan A. Brusko, ${ }^{8}$ Todd $M$. \\ Brusko, ${ }^{8}$ Erica O. Saphire, ${ }^{3}$ Thomas J. Connors, ${ }^{7}$ Alessandro Sette, ${ }^{3,9}$ Shane Crotty, ${ }^{3,9^{*}}$ and Donna L. Farber ${ }^{1,4^{*}}$
}

1Department of Microbiology and Immunology, Columbia University Irving Medical Center, New York, NY 10032, USA ${ }^{2}$ Medical Scientist Training Program, Columbia University Irving Medical Center, New York, NY 10032, USA ${ }^{3}$ Center of Infectious Disease and Vaccine Research, La Jolla Institute for Immunology, La Jolla, CA 92037, USA ${ }^{4}$ Department of Surgery, Columbia University Irving Medical Center, New York, NY 10032, USA ${ }^{5}$ Department of Systems Biology, Columbia University Irving Medical Center, New York, NY 10032, USA 6 Department of Pathology and Cell Biology, Columbia University Irving Medical Center, New York, NY 10032, USA DDepartment of Pediatrics, Columbia University Irving Medical Center, New York, NY 10032, USA 8Department of Pathology, Immunology, and Laboratory Medicine, University of Florida, Gainesville, FL 32611, USA ${ }^{9}$ Department of Medicine, Division of Infectious Diseases and Global Public Health, University of California, San Diego, La Jolla, CA 92037, USA

tequal contribution

*Corresponding author. Email: df2396@cumc.columbia.edu and shane@lji.org

Adaptive immune responses to SARS-CoV-2 infection have been extensively characterized in blood; however, most functions of protective immunity must be accomplished in tissues. Here, we report from examination of SARS-CoV-2 seropositive organ donors (ages $10-74$ ) that CD4 ${ }^{+} \mathrm{T}, \mathrm{CD} 8^{+} \mathrm{T}$, and $\mathrm{B}$ cell memory generated in response to infection is present in bone marrow, spleen, lung, and multiple lymph nodes (LNs) for up to 6 months post-infection. Lungs and lung-associated LNs were the most prevalent sites for SARS-CoV-2-specific memory $T$ and B cells, with significant correlations between circulating and tissue-resident memory $T$ and $B$ cells in all sites. We further identified SARS-CoV-2-specific germinal centers in the lung-associated LNs up to 6 months post-infection. SARS-CoV-2-specific follicular helper T cells were also abundant in lung-associated LNs and lungs. Together, the results indicate local tissue coordination of cellular and humoral immune memory against SARS-CoV-2 for site-specific protection against future infectious challenges.

\section{INTRODUCTION}

Ending the global COVID-19 pandemic caused by the novel coronavirus SARS-CoV-2 depends on the establishment of immunological memory. SARS-CoV-2 infects the respiratory tract and induces adaptive immune responses, resulting in virus-specific $\mathrm{T}$ and $\mathrm{B}$ lymphocytes mediating viral clearance at the infection site and inhibiting viral dissemination through $\mathrm{T}$ cell effector functions and antibodies. It is now well-documented that mild and severe infection generates circulating virus-specific $\mathrm{T}$ cells and antibodies detectable in peripheral blood for up to a year or more (1-8). Moreover, the presence of neutralizing antibodies specific for the viral Spike (S) protein correlates with protection for SARS-CoV-2 vaccines $(9,10)$. However, the emergence of viral variants with potential for immune evasion (11-15) and variability in vaccination rates among populations enable ongoing SARS-CoV2 spread. An understanding of the breadth and functional potential of virus-specific T and B cell memory is needed for developing improved strategies to protect against continually evolving strains.

A major limitation in studying human immune responses is that sampling is largely confined to peripheral blood, while adaptive immune responses are generated and carry out their protective functions in a range of tissues. Memory cells are also maintained in diverse tissues-including infection sites and lymphoid organs (reviewed in $(16,17)$ ). Virus-specific memory $\mathrm{CD} 4^{+}$and $\mathrm{CD} 8^{+} \mathrm{T}$ cells comprise heterogeneous subsets of circulating subsets and non-circulating tissue-resident memory cells $\left(\mathrm{T}_{\mathrm{RM}}\right)$ in various sites $(18,19)$. In mouse models, $\mathrm{T}_{\mathrm{RM}}$ in the lung mediate optimal protective responses to respiratory infection (20-22), and this localized protection also involves responses in lung-associated lymph nodes (LNs) (23, 24). In humans, the majority of T cells in adults are memory cells. The subset composition of human T cell memory is specific to the tissue site; in mucosal, exocrine, and barrier sites $\mathrm{T}_{\mathrm{RM}}$ predominate, while lymphoid sites contain circulating effector and central memory $\left(\mathrm{T}_{\mathrm{EM}}, \mathrm{T}_{\mathrm{CM}}\right.$ ) along with $\mathrm{T}_{\mathrm{RM}}$ subsets $(19,25,26)$. All types of memory T cells in tissues express gene expression signatures distinct from memory $\mathrm{T}$ cells in peripheral blood (27), suggesting that they are differentially maintained compared to circulation. In SARS-CoV-2 infection, activated $T_{E M}$ and $T_{R M}$ were identified in the airways of severe 
COVID-19 $(28,29)$, although the distribution and functional capacity of SARS-CoV-2-specific memory T cells across tissues remain uncharacterized.

The generation of memory B cells following an infection occurs in secondary lymphoid organs (LN, spleen) and requires virus-specific follicular helper $\mathrm{T}$ cells $\left(\mathrm{T}_{\mathrm{FH}}\right)$ which promote B cell differentiation, survival, and somatic hypermutation in germinal centers (GC) (30). Memory B cells can persist in multiple sites, and exhibit tissue-resident phenotypes (31). In mouse respiratory infection models, resident memory B cells $\left(\mathrm{B}_{\mathrm{RM}}\right)$ in lung and lung-associated LNs can be important for protection (32). In human lymphoid and mucosal sites, memory B cells are the predominant subset, while naïve B cells prevail in circulation (33). SARS-CoV-2 infection elicits generation of S-, receptor-binding domain (RBD)-, and nucleocapsid $(\mathrm{N})$-specific memory $\mathrm{B}$ cells detectable in peripheral blood $(1,3,7)$; however, the distribution and maintenance of SARS-CoV-2-specific memory B cells and GC B cells in tissues following natural infection have not been reported. Moreover, the relationship between human $\mathrm{B}$ and $\mathrm{T}$ cell memory in tissues is largely unexplored.

The use of physiologically healthy tissues from organ donors has enabled study of human immune cells across multiple sites $(16,34,35)$. Investigating tissue immunity to SARSCoV-2 is particularly challenging, as previously infected, but unvaccinated donors are required. Here, we present an investigation of SARS-CoV-2-specific memory T and B cell populations in lymphoid and mucosal sites of previously infected, seropositive organ donors, which we identified in bone marrow (BM), spleen, lung, and LNs up to 6 months post-infection. Lung and lung-associated LNs were the most prevalent sites for SARS-CoV-2-specific memory $\mathrm{T}$ and $\mathrm{B}$ cells, with a proportion exhibiting tissue-resident profiles. We also detected virus-specific GC B cells in lung-associated LNs along with $\mathrm{T}_{\mathrm{FH}}$, suggesting ongoing generation of humoral immunity. Together, our results reveal local coordination of cellular and humoral memory immune responses for site-specific protective immunity.

\section{RESULTS}

Organ donor cohorts for analysis of SARS-CoV-2specific immune responses in tissues

We have established a human tissue resource for obtaining multiple tissues from organ donors through collaborations with the organ procurement organizations $(16,34,35)$. Use of organ donor tissue allows for rapid isolation of live immune cells for functional analysis, thus enabling assessment of immune responses in multiple sites within an individual. We identified 4 organ donors ages 10-74 years with previous SARS-CoV-2 infection (Fig. 1A) who died of non-infectious-related causes and were SARS-CoV-2 PCR negative at the time of organ procurement. Previous SARS-CoV-2 infection history was based on post-procurement testing for antibodies to $\mathrm{N}$ protein (see Materials and Methods) and/or a confirmed history of COVID-19 2-6 months previously (Table S1). Controls were pre-pandemic seronegative organ donors procured prior to November 2019 who also died of noninfectious causes (Table S1).

All seropositive donors had detectable serum IgG to N, S, and RBD, along with SARS-CoV-2 neutralizing antibodies, consistent with antibody responses generated from acute infection $(36,37)$, while serum from pre-pandemic organ donors lacked antibodies to SARS-CoV-2 (Fig. 1B, C). Using this cohort, we examined SARS-CoV-2-specific T and B cell responses across blood, BM, spleen, lung, lung-associated LNs, and gut-associated LNs of seropositive and seronegative donors.

SARS-CoV-2-specific T cells in lung and lymphoid tissues

SARS-CoV-2-specific T cells in different sites from seropositive and seronegative organ donors were measured based on expression of $\mathrm{T}$ cell receptor-dependent activation-induced markers (AIMs) following stimulation with SARS-CoV2-specific peptide megapools (MPs), which enable simultaneous presentation of a large number of virus-specific epitopes $(2,38,39)$ (see fig. S1 and Materials and Methods). Mononuclear cells from each site were stimulated for 24 hours in vitro with four different SARS-CoV-2-specific MPs: MP_S (containing overlapping peptides representing the entirety of $S$ ), MP_CD4_R (containing predicted HLA class II viral epitopes minus S), MP_CD8_A and MP_CD8_B (each containing predicted HLA class I epitopes from all viral proteins) (2). SARSCoV-2-specific CD4 ${ }^{+} \mathrm{T}$ cells were identified based on co-expression of 2 or more of the following three AIMs (OX40, 41BB, and/or CD40L) (Fig. 1D, fig. S2A), while virus-reactive $\mathrm{CD}^{+} \mathrm{T}$ cells were identified based on co-expression of CD25 and 4-1BB (Fig. 1E, fig. S2B). Quantification of SARS-CoV-2specific $\mathrm{CD}^{+}$and $\mathrm{CD}^{+} \mathrm{T}$ cell responses was based on DMSObackground-subtracted frequencies of $\mathrm{AIM}^{+} \mathrm{CD}^{+}$and $\mathrm{CD} 8^{+}$ T cells (Fig. 1F, H).

For $\mathrm{CD} 4^{+} \mathrm{T}$ cells, significant responses to $\mathrm{S}$ protein were found in all sites examined (blood, BM, spleen, lung, lungassociated LNs, and gut-associated LNs) relative to pre-pandemic control samples (Fig. 1F, left panel). For non-S SARS$\mathrm{CoV}-2$ epitopes, there were significant $\mathrm{CD} 4^{+} \mathrm{T}$ cell frequencies in the BM, lung-associated LNs, and gut-associated LNs (Fig. $1 \mathrm{~F}$, right panel). Total SARS-CoV-2-specific $\mathrm{CD}^{+} \mathrm{T}$ cell responses largely reflected the pattern observed with S-specific responses (Fig. 1F, G). SARS-CoV-2-specific $\mathrm{CD}^{+} \mathrm{T}$ cell frequencies were generally lower in magnitude than for $\mathrm{CD}^{+} \mathrm{T}$ cells and more variable between donors (Fig. 1G-I). Significant SARS-CoV-2-specific $\mathrm{CD}^{+} \mathrm{T}$ cell frequencies above controls were observed for lung- and gut-associated LNs for class I epitopes (Fig. 1H, I). Comparing across all donors and sites, $\mathrm{CD}^{+} \mathrm{T}$ cells responding to $\mathrm{S}$ protein epitopes were the 
predominant SARS-CoV-2-specific $\mathrm{T}$ cells across tissue sites for all individuals (Fig. 1F, G, fig. S2C). While the distribution patterns of SARS-CoV-2-specific T cell responses across tissue sites varied between donors (Fig. 1 and S3), the lung and lungassociated LNs were most consistently the dominant sites for virus-specific $\mathrm{CD}^{+}{ }^{+}$and $\mathrm{CD}^{+}{ }^{+} \mathrm{T}$ cells (fig. $\mathrm{S} 2 \mathrm{D}$ ). These results indicate that SARS-CoV-2 infection generates virus-specific $\mathrm{T}$ cell responses across blood, multiple lymphoid sites, and lungs, with higher frequencies localized in lung tissue and lung-associated LNs.

SARS-CoV-2-specific $T$ cells are maintained in tissues as circulating and resident memory subsets

We analyzed the subset distribution of SARS-CoV-2specific $\mathrm{T}$ cells based on coordinate expression of CD45RA and CCR7, defining central memory $\mathrm{T}$ cells $\left(\mathrm{T}_{\mathrm{CM}}\right.$; CD45RA $\mathrm{CCR} 7^{+}$), effector memory $\mathrm{T}$ cells $\left(\mathrm{T}_{\mathrm{EM}}\right.$; CD45RACCR7 $7^{-}$, terminally differentiated effector $\mathrm{T}$ cells $\left(\mathrm{T}_{\mathrm{EMRA}}\right.$; $\left.\mathrm{CD} 45 \mathrm{RA}^{+} \mathrm{CCR} 7^{-}\right)$, and naïve or stem-like memory cells $\left(\mathrm{CD} 45 \mathrm{RA}^{+} \mathrm{CCR} 7^{+}\right)(40$, 41). Each tissue had a distinct $\mathrm{T}$ cell subset composition that is conserved between individuals as we previously determined $(26,35,42)$; $\mathrm{T}$ cell phenotypes for each site and for SARS-CoV-2-specific T cells are shown in representative flow cytometry plots (Fig. 2A). The majority of SARS-CoV-2specific $\mathrm{CD}^{+} \mathrm{T}$ cells were maintained as $\mathrm{T}_{\mathrm{EM}}(\geq 75 \%)$ in the blood and lung, and as $\mathrm{T}_{\mathrm{EM}}$ or $\mathrm{T}_{\mathrm{CM}}(\geq 80 \%)$ in lymphoid sites (Fig. 2B). For SARS-CoV-2-specific $\mathrm{CD}^{+} \mathrm{T}$ cells, the majority were maintained as $\mathrm{T}_{\mathrm{EM}}$ and $\mathrm{T}_{\mathrm{EMRA}}$ cells ( $250 \%$ ) for all sites; the proportion of $\mathrm{T}_{\mathrm{EMRA}}$ was higher than $\mathrm{T}_{\mathrm{EM}}$ for $\mathrm{BM}$, spleen, and lung, while $\mathrm{T}_{\mathrm{EM}}$ were more prevalent than $\mathrm{T}_{\mathrm{EMRA}}$ for $\mathrm{LNs}$ (Fig. 2C). Donors D495 and D498 had a particularly high proportion of SARS-CoV-2-specific CD8 ${ }^{+} \mathrm{T}_{\mathrm{EMRA}}$ cells in the lung, while the pediatric donor (HDL113) harbored more SARSCoV-2-specific CD45RA ${ }^{+} \mathrm{CCR} 7^{+} \mathrm{CD} 8^{+} \mathrm{T}$ cells in the lung and lung-associated LN (Fig. 2C).

We also analyzed co-expression of residency markers CD69 and CD103 by SARS-CoV-2-specific T cells (see fig. S1 for gating), as assessment of CD69 alone as a $\mathrm{T}_{\mathrm{RM}}$ marker was confounded due to CD69 up-regulation by TCR-stimulated T cells. Virus-specific $\mathrm{CD} 9^{+} \mathrm{CD}_{103}{ }^{+}$memory $\mathrm{CD}^{+}$and $\mathrm{CD}^{+} \mathrm{T}$ cells $\left(\mathrm{T}_{\mathrm{RM}}\right)$ were mostly confined to the lung, while lower frequencies of SARS-CoV-2-specific $\mathrm{CD}^{+} \mathrm{T}_{\mathrm{RM}}$ were also detected in LNs (Fig. 2D, E). Together, these results show that SARSCoV-2-specific $\mathrm{T}$ cells are maintained across diverse tissue sites as memory $\mathrm{T}$ cells, with a portion of $\mathrm{T}$ cells persisting as tissue-resident populations, particularly within the lung.

Tissue specificity and heterogeneity offunctional responses to SARS-CoV-2

The functional responses of SARS-CoV-2-responding cells from different sites were assessed by multiplex quantification of 50 immune mediators from culture supernatants of peptide-stimulated mononuclear cells as in Fig. 1. Blood and tissues exhibited distinct functional profiles, and the magnitude of responses varied between donors (Fig. 3A, fig. S4). Importantly, there was heterogeneity between individuals in the distribution of functional responses across sites. In particular, SARS-CoV-2-specific functional responses were primarily located in the lung for donor D492, in the lung-associated LN and blood for donor D495, while D498 and HDL113 exhibited a broad functional response across multiple sites (Fig. 3A). Interestingly, for both elderly donors (D492 and D498), lungassociated LN responses were much weaker compared to other tissue sites, even when the frequency $\mathrm{AIM}^{+} \mathrm{CD}^{+}$and $\mathrm{CD}^{+} \mathrm{T}$ cells in the lung-associated $\mathrm{LN}$ were high relative to other tissue sites (Fig. 3A, fig. S3). Overall, these data show that virus-specific functional responses are differentially maintained across sites and individuals.

Tissue-specific functional profiles were apparent in the profile of soluble mediators produced in response to stimulation with SARS-CoV-2 peptide pools (Fig. 3B, C). Importantly, the functional responses in the LN were the most diverse and included Type 1 proinflammatory cytokines and cytolytic mediators (IFN- $\gamma$, TNF- $\alpha$, granzyme B, perforin, GM-CSF), Type 2 cytokines (IL-5, IL-9, IL-13), and Type 3 cytokines (IL-17A, IL-17F, G-CSF) -most at increased levels compared to other sites (Fig. 3B, C). The functional response in the lung was distinct from other sites and included proinflammatory profiles (TNF- $\alpha$, perforin, granzyme, IL-12, IL-17A, G-CSF), IL-10 associated with regulation of inflammation during respiratory infections (43), and higher levels of IL-6 and the homeostatic cytokine IL-15 compared to other sites (Fig. 3B, C). BM responses were mostly TNF- $\alpha$, perforin, granzyme B, and IL-10 and blood responses were similar to BM (Fig. 3B, C). Comparing the immune mediator milieu between sites revealed that certain cytokines are produced across sites, while others are distinct to specific sites (Fig. 3C). Together, these results indicate that SARS-CoV-2-specific memory $\mathrm{T}$ cells in different sites exhibit distinct functional responses to viruses that are likely adapted to the site and contribute to a multifaceted protective response.

SARS-CoV-2-specific memory $B$ cells and resident phenotypes in tissues

To characterize the nature of memory $\mathrm{B}$ cell responses to SARS-CoV-2 in tissues, we used fluorescently-labeled, biotinylated, and multimerized probes of full-length $\mathrm{S}$ and RBD proteins to detect antigen-binding $\mathrm{B}$ cells among $\mathrm{IgM}^{+}, \mathrm{IgG}^{+}$, or IgA ${ }^{+}$memory B cells (Fig. S5A), as previously described (1). SARS-CoV-2-specific memory B cells were detected at frequencies substantially higher in seropositive subjects than seronegative subjects in all tissues examined, including lungs, BM, spleen, lung-associated LNs, and gut-associated LNs (Fig. 4A, B). Notably, $\mathrm{IgG}^{+}$was the dominant isotype of SARS-CoV-2-specific memory B cells in almost all samples, though IgM $^{+}$and IgA $\mathrm{A}^{+}$memory B cells were present (Fig. 4C). For D498, while few SARS-CoV-2-specific memory B cells 
were $\operatorname{IgM}^{+}$in the LNs, $>40 \%$ were $\operatorname{IgM}^{+}$in the BM and spleen. For D495, while almost no IgA+ SARS-CoV-2-specific memory B cells were found in the lung, $\sim 25 \%$ were $\operatorname{IgA}^{+}$in gut-associated LNs (Fig. 4C). SARS-CoV-2-specific memory B cells were present at significantly higher frequencies in lung and lungassociated LNs than in the spleen or gut-associated LNs (Fig. $4 \mathrm{~B}, \mathrm{D})$. The highest proportion of SARS-CoV-2-specific IgG ${ }^{+}$ memory B cells were found in the lung and lung-associated LNs (Fig. 4D).

Memory B cells can persist as tissue-resident cells $\left(\mathrm{B}_{\mathrm{RM}}\right)$ in lymphoid or non-lymphoid tissues, and are identified by CD69 expression $(32,33,44)$. In tissues of seropositive and seronegative donors, we detected significant populations (>50-75\%) of $\mathrm{CD} 69^{+} \mathrm{B}$ cells comprising $>50 \%$ of total B cells in the lungs and LNs, while BM and spleen contained much lower frequencies (0-10\%) of CD69-expressing B cells (Fig. S5B, C). Importantly, substantial frequencies of SARS-CoV-2specific memory B cells exhibited CD69 expression indicative of tissue resident profiles in lungs (50-80\%) and LNs (20$40 \%$ ) (Fig. 4E, F). By contrast, negligible frequencies (<3\%) of CD69 ${ }^{+}$SARS-CoV-2 S/RBD-specific memory B cells were detected in the BM of organ donors (Fig. $4 \mathrm{E}, \mathrm{F}$ ), and in peripheral blood samples from convalescent COVID-19 subjects (fig. S5D-I), consistent with previous analysis of polyclonal B cells in these sites (33). Together, these results provide direct evidence for human antigen-specific $B_{\mathrm{RM}}$ in lungs and LNs that are distinct from corresponding populations in blood. Thus, SARS-CoV-2 infection leads to the preferential formation and/or retention of antigen-specific $B$ cell memory within lungs and lung-associated LNs, with $\mathrm{CD} 69^{+}$tissue-resident cells representing the majority of the SARS-CoV-2 S-specific memory B cells in lungs.

\section{SARS-CoV-2-specific GC B cells and $T_{F H}$ cells in LNs}

GCs within lymphoid organs are important microanatomical sites in which activated B cells receive cognate help from $\mathrm{T}_{\mathrm{FH}}$ to undergo somatic hypermutation to evolve higher affinity antibody recognition of pathogens (45). While previous studies have demonstrated affinity matured SARS-CoV-2specific memory B cells in blood (3), BM plasma cells (46), and circulating virus-specific $\mathrm{T}_{\mathrm{FH}}$ cells (47), which all indicate GC responses in COVID-19 (48), direct evidence of SARS-CoV2 antigen-specific GCs (and S-specific GC B cells, in particular) is lacking. We identified GC B cells by assessing co-expression of Bcl6 (a transcription factor required for GC B cell differentiation (49)) and Ki67 (a marker of active cellular proliferation) among total CD19 ${ }^{+} \mathrm{B}$ cells (fig. S5A). The frequency of $\mathrm{GC} \mathrm{B}$ cells $\left(\mathrm{Bcl} 6^{+} \mathrm{Ki} 67^{+} \mathrm{CD} 19^{+} \mathrm{B}\right.$ cells) trended higher in lung-associated LNs of seropositive donors than seronegative donors (Fig. 5A, B; q = 0.053). SARS-CoV-2-specific GC B cells identified based on binding to $\mathrm{S}$ and $\mathrm{RBD}$ proteins were identified in lung-associated LNs of 3 out of 4 seropositive donors and in gut-associated LNs of one donor (Fig. 5C, D, fig. S5J).
Virus-specific GC B cells were not detected in BM, spleen, or lung of seropositive donors, nor in any tissues of seronegative donors (Fig. 5C, D). These results provide direct evidence that SARS-CoV-2-specific GC responses are induced by SARS-CoV2 infection and are maintained in lung-associated LNs following resolution of infection. Additionally, long-lasting GCs can even be generated in human gut-associated LNs.

$\mathrm{T}_{\mathrm{FH}}$ cells can be identified by co-expression of CXCR5 and PD-1 (50). $\mathrm{T}_{\mathrm{FH}}$-phenotype cells (CXCR5 ${ }^{+} \mathrm{PD}-1^{+} \mathrm{CD} 4^{+} \mathrm{T}$ cells) were found at low frequencies (5-10\%) in lymphoid sites (spleen, lung-associated LNs, gut-associated LNs) and in even lower frequencies in BM and most lungs of seronegative and seropositive donors (fig. S6), demonstrating the relative rarity of this population among total T cells. However, SARSCoV-2-specific $\mathrm{T}_{\mathrm{FH}}$ cells (identified by AIMs as in Fig. 1) were found in multiple sites of seropositive donors, comprising 20$50 \%$ of SARS-CoV-2-reactive $\mathrm{CD}^{+}{ }^{+} \mathrm{T}$ cells in LNs, and lower but significant frequencies in lung, spleen and BM (Fig. 5E$\mathrm{G})$. In one seropositive donor, over $80 \%$ of virus-specific $\mathrm{CD}^{+}$ $\mathrm{T}$ cells in the lung were $\mathrm{T}_{\mathrm{FH}}$, representing $\sim 4 \%$ of non-naïve SARS-CoV-2-specific CD4 ${ }^{+} \mathrm{T}$ cells, consistent with the higher overall frequency of $\mathrm{T}_{\mathrm{FH}}$ cells in the lungs of that donor (Fig. 5F, G, fig. S6). Together, the SARS-CoV-2-specific GC B cell and $\mathrm{T}_{\mathrm{FH}}$ data indicated robust GC responses to SARS-CoV-2 infection, distributed among lymphoid tissues and sites of viral infection, with some GCs being active for months postinfection.

\section{Coordinated adaptive immunity across tissues}

The identification of SARS-CoV-2-specific memory $\mathrm{T}$ and $\mathrm{B}$ cells in multiple tissues, along with $\mathrm{T}_{\mathrm{FH}}$ and GC B cells in LNs, suggested site-directed coordination of cellular and humoral immunity. In order to identify potential associations between SARS-CoV-2-specific lymphocyte populations across sites, we performed an exploratory correlation analysis (Fig. 6, fig. S7). The frequencies of S-specific CD4 ${ }^{+}$and $\mathrm{CD}^{+} \mathrm{T}$ cells (but not total SARS-CoV-2-specific T cells, fig. S7A) were positively correlated across tissue sites $(p=0.0116$; Fig. 6A). Significant associations also emerged between SARS-CoV-2specific B and T cells (Fig. 6B-F, fig. S7B-K)). SARS-CoV-2specific $\mathrm{CD}^{+} \mathrm{T}$ cell frequencies correlated positively with $\mathrm{S} / \mathrm{RBD}$-specific memory $\mathrm{B}$ cells across all tissues $(\mathrm{p}=0.0009)$, as well as $\mathrm{IgG}^{+}(\mathrm{p}=0.0009)$ and $\mathrm{IgA}^{+}(\mathrm{p}=0.0203)$ subpopulations (Fig. 6B, C, fig. S7D, E). For tissue-resident SARS-CoV2-specific lymphocytes, $\mathrm{CD} 69^{+} \mathrm{CD} 103^{+} \mathrm{CD}^{+} \mathrm{T}_{\mathrm{RM}}$ cells correlated with $\mathrm{CD} 69^{+} \mathrm{B}_{\mathrm{RM}}$ - both as frequencies of total lymphocytes $(p=0.0069)$ and as fractions within their respective antigen-specific populations $(\mathrm{p}=0.01)$ (Fig. 6E, fig. S7J). Positive correlations were also observed between $\mathrm{CD}^{+}{ }^{+} \mathrm{T}_{\mathrm{RM}}$ and $\mathrm{B}_{\mathrm{RM}}$ across all tissues $(\mathrm{p}=0.0198$; fig. $\mathrm{S} 7 \mathrm{I})$. For follicular responses, S/RBD-specific memory B cells correlated with SARS-CoV-2-specific $\mathrm{T}_{\mathrm{FH}}$ cells across tissues $(\mathrm{p}=0.0236$; Fig. $6 \mathrm{~F}$, fig. S7K). 
Given that lung and lung-associated LNs contained the highest frequencies of SARS-CoV-2-specific lymphocytes, we performed a targeted correlation matrix analysis to identify potential associations within and between these sites (Fig. 6G). SARS-CoV-2-specific $T_{\mathrm{FH}}$ cells in the lung-associated LNs were significantly associated with lung memory B cells, while SARS-CoV-2-specific CD4 ${ }^{+} \mathrm{T}$ cell frequencies positively correlated with SARS-CoV-2-specific GC B cells lung-associated LNs. Conversely, certain LN and lung populations were inversely correlated. In particular, the amount of S/RBDspecific GC B cells in the lung-associated LNs negatively correlated with S-specific CD4 ${ }^{+} \mathrm{T}$ cells in the lung. Similarly, $\mathrm{S} / \mathrm{RBD}$-specific memory B cell frequencies in the lung-associated LNs negatively correlated with SARS-CoV-2-specific and $\mathrm{S}$-specific $\mathrm{CD}^{+} \mathrm{T}$ cell frequencies in the lung. Similar correlations were observed when including blood and plasma antigen-specific lymphocyte populations in correlation matrix analyses (fig. S8). Together, these results suggest opposing or compensatory effects of humoral and cellular immune responses in lung-associated LNs and lungs.

\section{DISCUSSION}

Immunological memory is maintained by heterogeneous subsets of virus-specific $\mathrm{T}$ and $\mathrm{B}$ cells in non-lymphoid tissue sites of infection and multiple lymphoid organs. A comprehensive assessment of memory responses is therefore difficult to accomplish in humans. Here, we reveal the cellular complexity and functional diversity of SARS-CoV-2-specific memory $\mathrm{T}$ and $\mathrm{B}$ cells in lymphoid and mucosal tissues of previously infected organ donors up to 6 months post-infection (see fig. S9 for summary schematic). SARS-CoV-2-specific $\mathrm{CD}^{+}{ }^{+} \mathrm{T}, \mathrm{CD}^{+} \mathrm{T}$, and $\mathrm{B}$ cells predominantly localized in the lung and lung-associated LNs and were maintained as memory cell populations. Tissue-resident $\mathrm{T}$ and $\mathrm{B}$ cells, known to participate in protection against secondary viral infections, were found most abundantly in the lung and were correlated across multiple sites. Moreover, SARS-CoV-2specific GC B cells and $\mathrm{T}_{\mathrm{FH}}$ cells were discovered in lung-associated LNs, suggesting persisting GC responses months after resolution of infection. Together, these results indicate that the maintenance of SARS-CoV-2-specific immune memory is characterized by localized, ongoing coordination of cellular and humoral immunity within tissues.

SARS-CoV-2-specific memory $\mathrm{T}$ and $\mathrm{B}$ cells were found throughout the body and localized preferentially to lung and lung-associated LNs, providing direct evidence that those sites are key locations for establishment of immune memory after SARS-CoV-2 infection. Gut-draining LNs in some donors were also significant sites for SARS-CoV-2-specific memory $\mathrm{T}$ and $\mathrm{B}$ cells (particularly $\mathrm{T}_{\mathrm{RM}}$ and $\mathrm{B}_{\mathrm{RM}}$ ), which could be due to the gut being a major site for SARS-CoV-2 replication in some cases $(3,51)$. The low frequency of SARS-CoV-2-specific memory $\mathrm{T}$ or $\mathrm{B}$ cells in the spleen further suggests that virus infection is generally limited to mucosal sites of entry. While a proportion of memory $\mathrm{T}$ and $\mathrm{B}$ cells in the lung exhibited phenotypic markers of tissue residency, for $\mathrm{T}$ cells especially, assessing tissue residency in antigen-stimulated cultures can be complicated by induction of CD69 and other proteins, and further analysis is required to definitively establish the extent of $\mathrm{T}_{\mathrm{RM}}$ formation to SARS-CoV-2. In mouse models of influenza infection, localization and tissue residence of $\mathrm{T}$ and $\mathrm{B}$ cells to the lung and lung-associated LNs is correlated with optimal protective responses $(20,23,32)$. Therefore, tissue localized and resident memory $\mathrm{T}$ and $\mathrm{B}$ cells in the lung are likely important for site-specific protection and could be targets for site-specific boosting in vaccination.

SARS-CoV-2-specific memory $\mathrm{CD} 4^{+} \mathrm{T}$ cells were identified at significantly higher frequencies than $\mathrm{CD} 8^{+} \mathrm{T}$ cells across tissue sites, reflecting previous studies of peripheral blood showing that $\mathrm{CD} 4^{+}$responses are more robust than $\mathrm{CD} 8^{+}$responses months after resolution of infection $(2,52)$. In addition, SARS-CoV-2-specific $\mathrm{T}$ cells exhibited tissue-specific functional profiles, with cytotoxic proinflammatory, regulatory, and tissue repair functions variably manifested across different sites. In the lung-associated LNs, memory T cells exhibited broad proinflammatory, helper, and regulatory functional profiles. SARS-CoV-2-specific lung $\mathrm{T}$ cells produced higher levels of IL-10 compared to other sites, consistent with a role for T cell-derived IL-10 in regulating lung inflammation in mice (43). We previously showed in paired airway and blood samples of severe COVID-19 patients that the cytokine and chemokine profile in airway washes was distinct from that in plasma (28). Here, we further demonstrate that the functional responses of virus-specific T cells are tissue-specific - not only at the site of infection, but also across numerous lymphoid tissues. Together, these results suggest that $\mathrm{T}$ cells in tissues mediate responses that are functionally adapted to the tissue site, resulting in heterogeneity of immune memory stored throughout the body.

SARS-CoV-2-specific memory B cells were distributed across multiple sites. While frequencies were highest in lung and LNs, there were also significant frequencies in BM. In all sites, virus-specific memory B cells exhibited a predominantly $\mathrm{IgG}^{+}$memory phenotype. The finding of S/RBDspecific $\mathrm{B}_{\mathrm{RM}}$ in lung and lymphoid sites was notable, as was the low frequency of $\mathrm{IgA}^{+}$SARS-CoV-2-specific memory B cells in mucosal tissue and associate LNs.

Our results directly demonstrate ongoing, persistent GC responses in LNs following resolution of SARS-CoV-2 infection-including at least one example 6 months post-infection. Despite a report of potentially impaired GC responses in fatal COVID-19 (53), our data show coordinated $\mathrm{T}_{\mathrm{FH}}$ and GC B cells in the lung-associated LNs to non-fatal SARS-CoV-2 infection. These results provide evidence of ongoing GC reactions following resolution of infection, consistent with reports of 
prolonged evolution of humoral responses in peripheral blood up to 6 months following SARS-CoV-2 infection $(3,54)$. GC B cells were detected in donors spanning a broad age range-from 10-74 years, providing compelling evidence that the ability to establish robust GC responses to novel pathogens can be maintained with age.

These results also indicate ongoing interaction and coordination between $\mathrm{T}$ and $\mathrm{B}$ cells within LNs, which we also found related to memory populations in the lung. Significant correlations were also found between SARS-CoV-2-specific memory $\mathrm{B}$ and $\mathrm{T}$ cell populations across tissue sites, consistent with correlations between virus-specific $\mathrm{T}$ and $\mathrm{B}$ cell responses in peripheral blood of previously infected individuals $(1,7)$. We also identified potential inverse correlations between frequencies of virus-specific $\mathrm{CD} 8^{+} \mathrm{T}$ cells in the lung and memory B cells in the lung-associated LN, suggesting that lung responses in situ can impact the magnitude or requirement for humoral responses in the associated LN. Together, these findings suggest that dynamic coordination of adaptive immune responses across the body is a feature of antiviral immunity to SARS-CoV-2.

This work has certain limitations. Namely, our study focuses on four seropositive donors across seven decades of life to provide a representative profile of tissue-specific antiviral immune responses. In addition to the challenges of obtaining live cells for immunological studies from organ donors, the findings here also depended on SARS-CoV-2 seropositive subjects who had not been vaccinated, thus limiting the size of the donor pool and the timeframe of collection (prior to December 2020). The consistency in cell type and site-specific trends and correlations across all profiled donors, as well as corroboration of larger scale blood studies, demonstrates how this project provides new insights into tissue-specific immune memory maintenance and persistence of humoral and cellular responses following SARS-CoV-2 infection.

In conclusion, we reveal here that immunological memory from SARS-CoV-2 infection is maintained as heterogeneous subsets across multiple sites, with active and preferential maintenance in lung and associated LNs, as well as site-specific functional adaptations. These findings support the development of site-specific strategies for monitoring immune memory to infections and vaccines, and for fortifying immune responses at the infection sites.

\section{MATERIALS AND METHODS \\ Study design}

The objective of this study was to measure adaptive immune responses to SARS-CoV-2 in blood and tissues of seropositive individuals after resolution of infection. We measured the frequency of SARS-CoV-2-specific CD4 ${ }^{+} \mathrm{T}, \mathrm{CD} 8^{+}$ $\mathrm{T}$, and $\mathrm{B}$ cells in seropositive organ donors compared to prepandemic seronegative donors to understand the maintenance of immunological memory to SARS-CoV-2 as T and B cell subsets across the body, the functional immune response in tissues, and the immune memory relationships across circulating and tissue-resident SARS-CoV-2-specific T and B cell populations.

\section{Human samples}

Human tissues were obtained from deceased organ donors at the time of organ acquisition for clinical transplantation through an approved protocol and material transfer agreement with LiveOnNY, the organ procurement organization (OPO) for the New York metropolitan area, as previously described (34, 35, 55-59). Human tissues from the pediatric donor (HDL113) were obtained through arrangements with multiple OPOs across the US through the Human Atlas for Neonatal DeveLopment-immunity (HANDEL-I) program which is an extension of the coordinating center set up for nPOD (network for Pancreatic Organ Donors with Diabetes) (60). A list of donors from which tissues were used in this study is presented in Table S1. Organ donors are tested for SARS-CoV-2 infection (and confirmed as SARS-CoV-2 negative) by PCR testing of nasal swabs, tracheal aspirates, and/or bronchoalveolar lavage. A history of previous COVID-19 $(\mathrm{D} 492,498)$ and positive serology (D495) was provided in the donor summary and SARS-CoV-2 serology for all donors was measured in the Center for Advanced Laboratory Medicine at Columbia University Irving Medical Center. Tissues from all seropositive donors were obtained before December 2020, and all donors were free of cancer and seronegative for hepatitis B, C, and HIV. Because tissues are obtained from braindead organ donors, this study does not qualify as "human subjects" research, as confirmed by the Columbia University IRB.

\section{Isolation of single-cell suspensions from tissue sam-} ples

Tissue samples were maintained in cold saline or media and transported to the laboratory within 2-4 hours of organ procurement for adult organs, and shipped to the laboratory on ice within 24 hours of procurement for pediatric donors. Tissue processing protocols were adapted from protocols previously described $(34,55-59)$, with some recent optimizations. Briefly, mononuclear cells were isolated from the blood and BM samples by density centrifugation using Ficoll-Paque PLUS (GE, cat\# 17-1440-03). Spleen was processed using mechanical dissociation, followed by pushing through $100 \mu \mathrm{m}$ filters (Fisher Scientific, cat\# 50-146-1428), and Ficoll-Paque density centrifugation as above. Lung and lymph node samples were first incubated with $1 \mathrm{mg} / \mathrm{ml}$ Collagenase D (Sigma, cat\# 11088882001) and $0.1 \mathrm{mg} / \mathrm{ml}$ DNAse (Fisher Scientific, cat\# NC9709009) in Iscove's Modified Dulbecco's Medium (IMDM; Fisher Scientific, cat\#12-440-053) for $30 \mathrm{~min}$ at $37^{\circ} \mathrm{C}$ on a shaker followed by addition of EDTA $0.5 \mathrm{M} \mathrm{pH} 8.0$ (Fisher Scientific, cat\# 15-575-020), filtration and density centrifugation as above, resulting in high yields of live 


\section{leukocytes.}

\section{SARS-CoV-2 serology testing}

Blood from deceased organ donors (D495, D498, HDL113) was collected and serum obtained following centrifugation using serum separating clot activator tubes (Fisher Scientific, cat\# 22040546). SARS-CoV-2 serology testing for N protein was then performed by the Center for Advanced Laboratory Medicine (CALM) at Columbia University Irving Medical Center to determine previous exposure to SARS-CoV-2 for inclusion in the study.

SARS-CoV-2 ELISA titers were determined as previously described (1). Briefly, Corning 96-well half-area plates (ThermoFisher, Cat. No.3690) were coated with $1 \mu \mathrm{g} / \mathrm{mL}$ SARSCoV-2 S protein, RBD protein, or N protein (SinoBiological, Cat. No. 40588 -V07E) overnight at $4{ }^{\circ} \mathrm{C}$. The next day, plates were blocked with $3 \%$ milk (Skim Milk Powder ThermoFisher, Cat. No. LP0031) in PBS containing 0.05\% Tween20 (ThermoScientific, Cat. No. J260605-AP) for 2 hours at room temperature. Heat-inactivated serum $\left(30 \mathrm{~min}\right.$ at $\left.56^{\circ} \mathrm{C}\right)$ was then added to the plates and incubated for 1.5 hours at room temperature. Plates were washed 5 times with $0.05 \%$ PBS/Tween. Secondary antibodies were diluted in $1 \%$ milk containing $0.05 \%$ Tween-20 in PBS. IgG titers were determined using anti-human IgG peroxidase antibody (Hybridoma Reagent Laboratory, Cat. No. HP6123-HRP) at 1:1000 dilution. Endpoint titers were plotted for each sample using background subtracted data. The limit of detection was defined as 1:3 for IgG.

\section{Pseudovirus (PSV) Neutralization Assay}

The PSV neutralization assays were performed as previ-

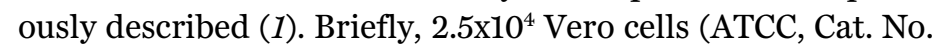
CCL-81) were seeded in clear flat-bottom 96-well plates (Thermo Scientific, Cat. No. 165305) to produce a monolayer at the time of infection. Recombinant SARS-CoV-2-S-D614G pseudotyped VSV- $\triangle \mathrm{G}$-GFP were generated by transfecting HEK293T cells (ATCC, Cat. No. CRL-321) with plasmid phCMV3-SARS-CoV2-Spike and then infecting with VSV- $\triangle$ GGFP. Pre-titrated rVSV-SARS-CoV-2-S-D614G was incubated with serially diluted human heat-inactivated serum at $37^{\circ} \mathrm{C}$ for 1-1.5 hours before addition to confluent Vero cell monolayers. Cells were incubated for 16 hours at $37^{\circ} \mathrm{C}$ in $5 \% \mathrm{CO}_{2}$ then fixed in $4 \%$ paraformaldehyde in PBS pH 7.4 (Santa Cruz, Cat. No. sc-281692) with $10 \mu \mathrm{g} / \mathrm{ml}$ Hoechst (Thermo Scientific, Cat. No. 62249) and imaged using a CellInsight CX5 imager to quantify the total number of cells and infected GFP-expressing cells to determine the percentage of infection. Neutralization titers or inhibition dose 50 (ID50) were calculated using the One-Site Fit Log IC50 model in Prism 8.0 (GraphPad). As internal quality control to define the interassay variation, three samples were included across the PSV neutralization assays. Samples that did not reach 50\% inhibition at the lowest serum dilution of 1:20 were considered as non-neutralizing.

In vitro T cell stimulations with SARS-CoV-2 peptide megapools (MPs)

Mononuclear cells from blood, BM, spleen, lung, lung-associated LNs, and gut-associated LNs of SARS-CoV-2 seropositive donors were thawed, and dead cells were removed using the EasySep Dead Cell Removal (Annexin V) Kit (STEMCELL Technologies, cat\# 17899) containing 10\% heatinactivated human $\mathrm{AB}$ serum (Gemini, cat\# 507533010) and Penicillin-Streptomycin-Glutamine (ThermoFisher Scientific, cat\# 10378016) and incubated overnight at $37^{\circ} \mathrm{C}, 5 \% \mathrm{CO}_{2}$. Cells were stimulated for 6 or 24 hours by the addition of SARSCoV-2-specific CD4 and CD8 MPs $(1 \mu \mathrm{g} / \mathrm{mL})$ (MP_S, MP_CD4_R, MP_CD8_A, MP_CD8_B) designed and synthesized as previously described. Briefly, MP_S consists of 253 15-mer peptides overlapping by 10 residues and covering the entire S protein. MP_CD4_R consists of 221 predicted HLA class II CD4 ${ }^{+} \mathrm{T}$ cell epitopes covering all proteins apart from $\mathrm{S}$ protein. For CD8 epitopes, MPs were synthesized based on epitope predictions for 12 most common HLA class I A and B alleles; these resulted in 628 predicted $\mathrm{CD} 8^{+} \mathrm{T}$ cell epitopes, which were separated into MP_CD8_A and MP_CD8_B (1, 2, 61). Equimolar amount of dimethyl sulfoxide (DMSO) was used as negative control. Prior to the addition of peptide MPs, cells were blocked for $15 \mathrm{~min}$ with $0.5 \mu \mathrm{g} / \mathrm{mL}$ of anti-CD40 monoclonal antibody (Miltenyi Biotec, cat\# 130-094-133), as previously described (62). After either 6 or 24 hours, supernatant was collected for multiplex detection of cytokines, and cells were stained for AIMs and analyzed via flow cytometry.

$\mathrm{AIM}^{+}$antigen-specific $\mathrm{CD} 4^{+} \mathrm{T}$ cells were identified as positive following Boolean OR gating of the $\mathrm{CD}_{40 \mathrm{~L}^{+}} \mathrm{OX} 40^{+}$, 4$1 \mathrm{BB}^{+} \mathrm{OX} 40^{+}$, 4-1BB ${ }^{+} \mathrm{CD} 40 \mathrm{~L}^{+}$subsets (see Fig. S1 for gating strategy). The resultant gate was used to quantify $\mathrm{AIM}^{+} \mathrm{CD} 4^{+} \mathrm{T}$ cell frequency. $\mathrm{AIM}^{+}$antigen-specific $\mathrm{CD} 8^{+} \mathrm{T}$ cells were identified as $4-1 \mathrm{BB}^{+} \mathrm{CD} 25^{+}$. Antigen-specific $\mathrm{T}_{\mathrm{FH}}$ calculated as a frequency of non-naïve (NN) $\mathrm{CD}^{+} \mathrm{T}$ cells were gated on total $\mathrm{CD}^{+}{ }^{+} \mathrm{T}$ cells excluding $\mathrm{CD} 45 \mathrm{RA}^{+} \mathrm{CCR} 7^{+} \mathrm{CD} 4^{+} \mathrm{T}$ cells. Antigenspecific $\mathrm{CD}^{+}$and $\mathrm{CD}^{+}{ }^{+} \mathrm{T}$ cells were measured as DMSObackground-subtracted data. For quantification of the frequency of total SARS-CoV-2-specific $\mathrm{CD}^{+} \mathrm{T}$ cells, a weighted average was taken for percentage of $\mathrm{AIM}^{+} \mathrm{CD} 4^{+} \mathrm{T}$ cells identified for samples stimulated with MP_S or MP_CD4_R MPs. For quantification of the frequency of total SARS-CoV-2specific $\mathrm{CD}^{+} \mathrm{T}$ cells, a weighted average was taken for percentage of $\mathrm{AIM}^{+} \mathrm{CD}^{+} \mathrm{T}$ cells identified for samples stimulated with MP_S, MP_CD8_A, or MP_CD8_B MPs.

\section{Flow cytometry}

For flow cytometry analysis of SARS-CoV-2 antigen-reactive $\mathrm{T}$ cells, cells were stained in 96 -well U-bottom plates protected from light using fluorochrome-conjugated antibodies (see Table S2 for antibodies in the $\mathrm{T}$ cell flow cytometry panel). Briefly, cells were washed with FACS-buffer (PBS with 
$2 \%$ heat-inactivated FBS), then resuspended with surface staining antibody cocktail for $20 \mathrm{~min}$ at room temperature. Surface-stained cells were fixed for $30 \mathrm{~min}$ at RT in fixation buffer (Tonbo, cat\# TNB-0607-KIT), washed with permeabilization buffer (Tonbo, cat\# TNB-0607-KIT), and washed again with FACS buffer. Flow cytometry data were collected using the 5-laser Cytek Aurora flow cytometer (Cytek Bio) and analyzed using FlowJo V 10.7 software and Prism 9.0.1. software.

For flow cytometry analysis of SARS-CoV-2-specific B cells, biotinylated protein antigens multimerized on fluorescently-labeled streptavidin were used as probes to detect antigen-specific B cells (see Table S3 for antibodies used in the B cell flow cytometry panel). Avi-tagged full-length SARSCoV-2 S (2P-stabilized, double streptavidin-tagged) and RBD proteins were generated in-house. Biotinylation was performed using biotin protein ligase standard reaction kit (Avidity, cat\# Bir500A) following the manufacturers protocol and dialyzed against PBS. Biotinylated $\mathrm{S}$ was mixed with streptavidin BV421 (BioLegend, cat\# 405225) and streptavidin BUV737 (BD Bioscience, cat \# 612775) at 20:1 ratio ( 6:1 molar ratio). Biotinylated $\mathrm{RBD}$ was mixed with streptavidin PE-Cy7 (BioLegend, cat\# 405206) and streptavidin BUV661 (BD Bioscience, cat\# 612979) at 2.2:1 ratio ( 4:1 molar ratio). Streptavidin PE-Cy5.5 (Thermo Fisher Scientific, cat\# SA1018) was used as a decoy probe for non-specific streptavidin-binding B cells. The probes were then mixed in Brilliant Stain Buffer (BD Bioscience, Cat\# 566349) containing 5 $\mathrm{M}$ M free dbiotin (Avidity, Cat\# Bir500A). Cells $\left(\sim 10^{7}\right)$ were prepared in U-bottom 96 -well plates and stained with $50 \mu \mathrm{L}$ antigen cocktail containing 400ng S (200ng per probe), 100ng RBD (50ng per probe), and 20ng streptavidin PE-Cy5.5 at $4^{\circ} \mathrm{C}$ for one hour followed by staining for surface markers in Brilliant Stain Buffer at $4^{\circ} \mathrm{C}$ for $30 \mathrm{~min}$. Dead cells were stained using LIVE/DEAD Fixable Blue Stain Kit (Thermo Fisher Scientific, Cat\# L34962) in PBS at $4^{\circ} \mathrm{C}$ for $30 \mathrm{~min}$. Cells were then fixed and permeabilized using eBioscience Intracellular Fixation \& Permeabilization Buffer Set (Thermo Fisher Scientific, Cat\# 88-8824-00) before staining with antibodies against transcription factors in eBioscience Permeabilization Buffer (Thermo Fisher Scientific, Cat\# 00-8333-56). Samples were acquired on Cytek Aurora and analyzed using FlowJo10.7.1 (BD Bioscience). In each experiment, PBMCs from a known COVID-19 convalescent subject and an unexposed subject were included to ensure consistent sensitivity and specificity of the assay.

\section{Multiplex detection of cytokines}

Cryopreserved supernatant from in vitro $\mathrm{T}$ cell stimulation experiments were sent to Eve Technologies Corp. (Calgary, Alberta) for quantification of 50 total human cytokines, chemokines, and growth factors. Luminex xMAP technology was used for multiplexed quantification of 2 human cytokines in one array (perforin, granzyme B) and 48 human cytokines, chemokines, and growth factors in a separate array (sCD40L, EGF, Eotaxin, FGF-2, Flt-3 ligand, Fractalkine, G-CSF, GM$\mathrm{CSF}, \mathrm{GRO} \alpha$, IFN $\alpha 2$, IFN $\gamma$, IL-1 $\alpha$, IL-1 $\beta$, IL-1ra, IL-2, IL-3, IL4, IL-5, IL-6, IL-7, IL-8, IL-9, IL-10, IL-12 (p40), IL-12 (p70), IL-13, IL-15, IL-17A, IL-17E/IL-25, IL-17F, IL-18, IL-22, IL-27, IP-10, MCP-1, MCP-3, M-CSF, MDC (CCL22), MIG, MIP-1 $\alpha$, MIP-1 $\beta$, PDGF-AA, PDGF-AB/BB, RANTES, TGF $\alpha, \mathrm{TNF} \alpha$, TNF $\beta$, VEGF-A). The multiplexing analysis was performed using the Luminex 200 system with assay kits sourced by Millipore MILLIPEX (MilliporeSigma, Burlington, Massachusetts, USA) according to the manufacturer's protocol.

Observed concentrations were calculated with the standard curve based on the fluorescence intensity of the bead population for a specific analyte. For analysis and visualization of cytokine/chemokine production by antigen-responding cells in multiple tissues sites within each individual donor, observed concentrations for each analyte were first subtracted from DMSO negative control then scaled across samples for each individual donor on a maximum absolute scale, with values ranging from -1 to 1 across all analytes, using the MaxAbsScaler features of sklearn.preprocessing function of the Python scikit-learn library $(36,63)$. Heatmap visualizations were generated using the Python data visualization library seaborn (64). For analysis comparing the production of analytes across donors and tissue sites, either absolute observed concentrations were used or observed concentrations for each analyte were normalized to DMSO negative control.

\section{Correlogram plot and visualization}

Correlograms were analyzed and plotted using the Pearson product moment correlation coefficient ( $\mathrm{r}$ ) between all parameter pairs from blood, lung, and lung-associated LN lymphocyte populations (see Data File 2 for raw data, R and $\mathrm{p}$ values). Correlograms were created with the corrplot package (v0.88) (65) running under $\mathrm{R}$ (v4.0.2) in RStudio (1.4.1103). Visual clustering of parameters was performed using the 'hclust' option of corrMatOrder. Two-sided p-values were calculated using corr.test (stats v4.0.2) and graphed (corrplot v0.88) based on *, p $\leq 0.05$; **, $\mathrm{p} \leq 0.01$; ${ }^{* *}, \mathrm{p} \leq$ 0.001 .

\section{Statistical analysis}

Descriptive statistics of compiled flow cytometry data and statistical testing were performed using Prism (GraphPad). Graphs were generated using Prism (GraphPad), Python matplotlib and seaborn libraries $(64,66)$, and RStudio corrplot package (65). Differences in means between two sample groups were compared using nonparametric test of null hypothesis Mann-Whitney U test. Pearson correlations were used to evaluate immune memory relationships. Multiple group comparisons were done using one-way ANOVA, corrected for multiple comparisons by false discovery rate (FDR) using two-stage linear step-up procedure of Benjamini, Krieger, and Yekutieli when comparing seropositive and 
seronegative donors. For comparing immune mediator profiles across tissue sites, statistical analyses were performed via one-way ANOVA, corrected for multiple comparisons by Tukey's multiple comparison test. $P$-values below 0.05 were considered as statistically significant. For all figures, ${ }^{* * * *} \mathrm{de}-$ notes p-value $\leq 0.0001, * * *$ denotes p-value $\leq 0.001$, $* *$ denotes p-value $\leq 0.01$, and $*$ denotes p-value $\leq 0.05$.

\section{SUPPLEMENTARY MATERIALS}

www.science.org/doi/10.1126/sciimmunol.abl9105

Fig. S1. T cell flow cytometry gating strategy.

Fig. S2. SARS-CoV-2 reactive $\mathrm{CD} 4^{+}$and $\mathrm{CD} 8^{+} \mathrm{T}$ cells across seropositive donors and tissue sites

Fig. S3. SARS-CoV-2-specific CD4+ and $\mathrm{CD} 8^{+} T$ cells in blood and tissues of individual seropositive donors.

Fig. S4. Cytokine, chemokine, and growth factor production following stimulation with SARS-CoV-2 antigens across tissue sites.

Fig. S5. Tissue memory and germinal center B cell responses following natural exposure to SARS-CoV-2.

Fig. S6. Follicular helper T cell frequencies across tissue sites.

Fig. S7. SARS-CoV-2-specific immune memory relationships across organs.

Fig. S8. Correlogram of SARS-CoV-2-specific, blood, lung and lung-associated LN lymphocyte populations

Fig. S9. Graphical representation of workflow and SARS-CoV-2-specific lymphocyte frequencies across human tissues.

Table S1. Information about donors in this study.

Table S2. T cell flow cytometry panel.

Table S3. B cell flow cytometry panel.

Data file S1. Related to Figures 3 and S4. Compiled raw data of DMSO background subtracted analyte concentrations.

Data file S2. Raw data file related to Figures 1-6, S3, S4, S5, S6, S7, S8 (Excel spreadsheet).

\section{REFERENCES AND NOTES}

1. J. M. Dan, J. Mateus, Y. Kato, K. M. Hastie, E. D. Yu, C. E. Faliti, A. Grifoni, S. I. Ramirez, S. Haupt, A. Frazier, C. Nakao, V. Rayaprolu, S. A. Rawlings, B. Peters, F. Krammer, V. Simon, E. O. Saphire, D. M. Smith, D. Weiskopf, A. Sette, S. Crotty, Immunological memory to SARS-CoV-2 assessed for up to 8 months after infection. Science 371, ・. (2021). doi:10.1126/science.abf4063 Medline

2. A. Grifoni, D. Weiskopf, S. I. Ramirez, J. Mateus, J. M. Dan, C. R. Moderbacher, S. A. Rawlings, A. Sutherland, L. Premkumar, R. S. Jadi, D. Marrama, A. M. de Silva, A. Frazier, A. F. Carlin, J. A. Greenbaum, B. Peters, F. Krammer, D. M. Smith, S. Crotty, A. Sette, Targets of T Cell Responses to SARS-CoV-2 Coronavirus in Humans with COVID-19 Disease and Unexposed Individuals. Cell 181, 14891501.e15 (2020). doi:10.1016/i.cell.2020.05.015 Medline

3. C. Gaebler, Z. Wang, J. C. C. Lorenzi, F. Muecksch, S. Finkin, M. Tokuyama, A. Cho, M. Jankovic, D. Schaefer-Babajew, T. Y. Oliveira, M. Cipolla, C. Viant, C. O. Barnes, Y. Bram, G. Breton, T. Hägglöf, P. Mendoza, A. Hurley, M. Turroja, K. Gordon, K. G. Millard, V. Ramos, F. Schmidt, Y. Weisblum, D. Jha, M. Tankelevich, G. MartinezDelgado, J. Yee, R. Patel, J. Dizon, C. Unson-O'Brien, I. Shimeliovich, D. F. Robbiani, Z. Zhao, A. Gazumyan, R. E. Schwartz, T. Hatziioannou, P. J. Bjorkman, S. Mehandru, P. D. Bieniasz, M. Caskey, M. C. Nussenzweig, Evolution of antibody immunity to SARS-CoV-2. Nature 591, 639-644 (2021). doi:10.1038/s41586021-03207-w Medline

4. Z. Wang, F. Muecksch, D. Schaefer-Babajew, S. Finkin, C. Viant, C. Gaebler, H. H. Hoffmann, C. O. Barnes, M. Cipolla, V. Ramos, T. Y. Oliveira, A. Cho, F. Schmidt, J. Da Silva, E. Bednarski, L. Aguado, J. Yee, M. Daga, M. Turroja, K. G. Millard, M. Jankovic, A. Gazumyan, Z. Zhao, C. M. Rice, P. D. Bieniasz, M. Caskey, T. Hatziioannou, M. C. Nussenzweig, Naturally enhanced neutralizing breadth against SARS-CoV-2 one year after infection. Nature 595, 426-431 (2021). doi:10.1038/s41586-021-03696-9 Medline

5. L. B. Rodda, J. Netland, L. Shehata, K. B. Pruner, P. A. Morawski, C. D. Thouvenel, K. K. Takehara, J. Eggenberger, E. A. Hemann, H. R. Waterman, M. L. Fahning, Y. Chen, M. Hale, J. Rathe, C. Stokes, S. Wrenn, B. Fiala, L. Carter, J. A. Hamerman,
N. P. King, M. Gale Jr., D. J. Campbell, D. J. Rawlings, M. Pepper, Functional SARSCoV-2-Specific Immune Memory Persists after Mild COVID-19. Cell 184, 169183.e17 (2021). doi:10.1016/i.cell.2020.11.029 Medline

6. T. Bilich, A. Nelde, J. S. Heitmann, Y. Maringer, M. Roerden, J. Bauer, J. Rieth, M. Wacker, A. Peter, S. Hörber, D. Rachfalski, M. Märklin, S. Stevanović, H. G. Rammensee, H. R. Salih, J. S. Walz, T cell and antibody kinetics delineate SARSCoV-2 peptides mediating long-term immune responses in COVID-19 convalescent individuals. Sci. Transl. Med. 13, eabf7517 (2021). doi:10.1126/scitransImed.abf7517 Medline

7. K. W. Cohen, S. L. Linderman, Z. Moodie, J. Czartoski, L. Lai, G. Mantus, C. Norwood, L. E. Nyhoff, V. V. Edara, K. Floyd, S. C. De Rosa, H. Ahmed, R. Whaley, S. N. Patel, B. Prigmore, M. P. Lemos, C. W. Davis, S. Furth, J. B. O'Keefe, M. P. Gharpure, S. Gunisetty, K. Stephens, R. Antia, V. I. Zarnitsyna, D. S. Stephens, S. Edupuganti, N. Rouphael, E. J. Anderson, A. K. Mehta, J. Wrammert, M. S. Suthar, R. Ahmed, M. J. McElrath, Longitudinal analysis shows durable and broad immune memory after SARS-CoV-2 infection with persisting antibody responses and memory B and T cells. Cell Rep Med 2, 100354 (2021). doi:10.1016/j.xcrm.2021.100354 Medline

8. J. Zuo, A. C. Dowell, H. Pearce, K. Verma, H. M. Long, J. Begum, F. Aiano, Z. AminChowdhury, K. Hoschler, T. Brooks, S. Taylor, J. Hewson, B. Hallis, L. Stapley, R. Borrow, E. Linley, S. Ahmad, B. Parker, A. Horsley, G. Amirthalingam, K. Brown, M. E. Ramsay, S. Ladhani, P. Moss, Robust SARS-CoV-2-specific T cell immunity is maintained at 6 months following primary infection. Nat. Immunol. 22, 620-626 (2021). doi:10.1038/s41590-021-00902-8 Medline

9. D. S. Khoury, D. Cromer, A. Reynaldi, T. E. Schlub, A. K. Wheatley, J. A. Juno, K. Subbarao, S. J. Kent, J. A. Triccas, M. P. Davenport, Neutralizing antibody levels are highly predictive of immune protection from symptomatic SARS-CoV-2 infection. Nat. Med. 27, 1205-1211 (2021). doi:10.1038/s41591-021-01377-8 Medline

10. K. A. Earle, D. M. Ambrosino, A. Fiore-Gartland, D. Goldblatt, P. B. Gilbert, G. R Siber, P. Dull, S. A. Plotkin, Evidence for antibody as a protective correlate for COVID-19 vaccines. Vaccine 39, 4423-4428 (2021). doi:10.1016/i.vaccine.2021.05.063 Medline

11. S. S. Abdool Karim, T. de Oliveira, New SARS-CoV-2 Variants - Clinical, Public Health, and Vaccine Implications. N. Engl. J. Med. 384, 1866-1868 (2021) doi:10.1056/NEJMc2100362 Medline

12. L. J. Abu-Raddad, H. Chemaitelly, A. A. Butt; National Study Group for COVID-19 Vaccination, Effectiveness of the BNT162b2 Covid-19 Vaccine against the B.1.1.7 and B.1.351 Variants. N. Engl. J. Med. 385, 187-189 (2021) doi:10.1056/NEJMc2104974 Medline

13. R. E. Chen, X. Zhang, J. B. Case, E. S. Winkler, Y. Liu, L. A. VanBlargan, J. Liu, J. M. Errico, X. Xie, N. Suryadevara, P. Gilchuk, S. J. Zost, S. Tahan, L. Droit, J. S. Turner, W. Kim, A. J. Schmitz, M. Thapa, D. Wang, A. C. M. Boon, R. M. Presti, J. A. O'Halloran, A. H. J. Kim, P. Deepak, D. Pinto, D. H. Fremont, J. E. Crowe Jr., D. Corti, H. W. Virgin, A. H. Ellebedy, P. Y. Shi, M. S. Diamond, Resistance of SARS-CoV-2 variants to neutralization by monoclonal and serum-derived polyclonal antibodies. Nat. Med. 27, 717-726 (2021). doi:10.1038/s41591-021-01294-w Medline

14. N. R. Faria, T. A. Mellan, C. Whittaker, I. M. Claro, D. D. S. Candido, S. Mishra, M. A. E. Crispim, F. C. S. Sales, I. Hawryluk, J. T. McCrone, R. J. G. Hulswit, L. A. M Franco, M. S. Ramundo, J. G. de Jesus, P. S. Andrade, T. M. Coletti, G. M. Ferreira, C. A. M. Silva, E. R. Manuli, R. H. M. Pereira, P. S. Peixoto, M. U. G. Kraemer, N. Gaburo Jr., C. D. C. Camilo, H. Hoeltgebaum, W. M. Souza, E. C. Rocha, L. M. de Souza, M. C. de Pinho, L. J. T. Araujo, F. S. V. Malta, A. B. de Lima, J. D. P. Silva, D. A. G. Zauli, A. C. S. Ferreira, R. P. Schnekenberg, D. J. Laydon, P. G. T. Walker, H. M. Schlüter, A. L. P. Dos Santos, M. S. Vidal, V. S. Del Caro, R. M. F. Filho, H. M. Dos Santos, R. S. Aguiar, J. L. Proença-Modena, B. Nelson, J. A. Hay, M. Monod, X. Miscouridou, H. Coupland, R. Sonabend, M. Vollmer, A. Gandy, C. A. Prete Jr., V. H. Nascimento, M. A. Suchard, T. A. Bowden, S. L. K. Pond, C. H. Wu, O. Ratmann, N. M. Ferguson, C. Dye, N. J. Loman, P. Lemey, A. Rambaut, N. A. Fraiij, M. D. P. S. S. Carvalho, O. G. Pybus, S. Flaxman, S. Bhatt, E. C. Sabino, Genomics and epidemiology of the P.1SARS-CoV-2 lineage in Manaus, Brazil. Science 372, 815821 (2021). doi:10.1126/science. abh2644 Medline

15. M. McCallum, A. De Marco, F. A. Lempp, M. A. Tortorici, D. Pinto, A. C. Walls, M. Beltramello, A. Chen, Z. Liu, F. Zatta, S. Zepeda, J. di Iulio, J. E. Bowen, M. MontielRuiz, J. Zhou, L. E. Rosen, S. Bianchi, B. Guarino, C. S. Fregni, R. Abdelnabi, S. C. 
Foo, P. W. Rothlauf, L. M. Bloyet, F. Benigni, E. Cameroni, J. Neyts, A. Riva, G. Snell, A. Telenti, S. P. J. Whelan, H. W. Virgin, D. Corti, M. S. Pizzuto, D. Veesler, Nterminal domain antigenic mapping reveals a site of vulnerability for SARS-CoV2. Cell 184, 2332-2347.e16 (2021). doi:10.1016/i.cell.2021.03.028 Medline

16. D. L. Farber, Tissues, not blood, are where immune cells function. Nature 593 , 506-509 (2021). doi:10.1038/d41586-021-01396-y Medline

17. S. P. Weisberg, B. B. Ural, D. L. Farber, Tissue-specific immunity for a changing world. Cell 184, 1517-1529 (2021). doi:10.1016/i.cell.2021.01.042 Medline

18. D. Masopust, A. G. Soerens, Tissue-Resident T Cells and Other Resident Leukocytes. Annu. Rev. Immunol. 37, 521-546 (2019). doi:10.1146/annurevimmunol-042617-053214 Medline

19. P. A. Szabo, M. Miron, D. L. Farber, Location, location, location: Tissue resident memory T cells in mice and humans. Sci. Immunol. 4, eaas9673 (2019). doi:10.1126/sciimmunol.aas9673 Medline

20. J. R. Teijaro, D. Turner, Q. Pham, E. J. Wherry, L. Lefrançois, D. L. Farber, Cutting edge: Tissue-retentive lung memory CD4 T cells mediate optimal protection to respiratory virus infection. J. Immunol. 187, 5510-5514 (2011). doi:10.4049/iimmunol.1102243 Medline

21. T. Wu, Y. Hu, Y. T. Lee, K. R. Bouchard, A. Benechet, K. Khanna, L. S. Cauley, Lungresident memory CD8 T cells (TRM) are indispensable for optimal crossprotection against pulmonary virus infection. J. Leukoc. Biol. 95, 215-224 (2014). doi:10.1189/ilb.0313180 Medline

22. J. Zhao, J. Zhao, A. K. Mangalam, R. Channappanavar, C. Fett, D. K. Meyerholz, S. Agnihothram, R. S. Baric, C. S. David, S. Perlman, Airway Memory CD4(+) T Cells Mediate Protective Immunity against Emerging Respiratory Coronaviruses. Immunity 44, 1379-1391 (2016). doi:10.1016/j,immuni.2016.05.006 Medline

23. D. H. Paik, D. L. Farber, Anti-viral protective capacity of tissue resident memory $T$ cells. Curr. Opin. Virol. 46, 20-26 (2021). doi:10.1016/j.coviro.2020.09.006 Medline

24. D. H. Paik, D. L. Farber, Influenza infection fortifies local lymph nodes to promote lung-resident heterosubtypic immunity. J. Exp. Med. 218, e20200218 (2021). doi:10.1084/jem.20200218 Medline

25. J. Kubler-Kielb, F. Majadly, Z. Biesova, C. P. Mocca, C. Guo, R. Nussenzweig, V. Nussenzweig, S. Mishra, Y. Wu, L. H. Miller, J. M. Keith, T. Y. Liu, J. B. Robbins, R. Schneerson, A bicomponent Plasmodium falciparum investigational vaccine composed of protein-peptide conjugates. Proc. Natl. Acad. Sci. U.S.A. 107, $1172-$ 1177 (2010). doi:10.1073/pnas.0913374107 Medline

26. B. V. Kumar, T. J. Connors, D. L. Farber, Human T Cell Development, Localization, and Function throughout Life. Immunity 48, 202-213 (2018). doi:10.1016/i.immuni.2018.01.007 Medline

27. P. A. Szabo, H. M. Levitin, M. Miron, M. E. Snyder, T. Senda, J. Yuan, Y. L. Cheng, E. C. Bush, P. Dogra, P. Thapa, D. L. Farber, P. A. Sims, Single-cell transcriptomics of human $T$ cells reveals tissue and activation signatures in health and disease. Nat. Commun. 10, 4706 (2019). doi:10.1038/s41467-019-12464-3 Medline

28. P. A. Szabo, P. Dogra, J. I. Gray, S. B. Wells, T. J. Connors, S. P. Weisberg, I. Krupska, R. Matsumoto, M. M. L. Poon, E. Idzikowski, S. E. Morris, C. Pasin, A. J. Yates, A. Ku, M. Chait, J. Davis-Porada, X. V. Guo, J. Zhou, M. Steinle, S. Mackay, A. Saqi, M. R. Baldwin, P. A. Sims, D. L. Farber, Longitudinal profiling of respiratory and systemic immune responses reveals myeloid cell-driven lung inflammation in severe COVID-19. Immunity 54, 797-814.e6 (2021). doi:10.1016/i.immuni.2021.03.005 Medline

29. M. Liao, Y. Liu, J. Yuan, Y. Wen, G. Xu, J. Zhao, L. Cheng, J. Li, X. Wang, F. Wang, L. Liu, I. Amit, S. Zhang, Z. Zhang, Single-cell landscape of bronchoalveolar immune cells in patients with COVID-19. Nat. Med. 26, 842-844 (2020). doi:10.1038/s41591-020-0901-9 Medline

30. S. Crotty, T Follicular Helper Cell Biology: A Decade of Discovery and Diseases. Immunity 50, 1132-1148 (2019). doi:10.1016/i.immuni.2019.04.011 Medline

31. F. Weisel, M. Shlomchik, Memory B Cells of Mice and Humans. Annu. Rev. Immunol. 35, 255-284 (2017). doi:10.1146/annurev-immunol-041015-055531 Medline

32. S. R. Allie, J. E. Bradley, U. Mudunuru, M. D. Schultz, B. A. Graf, F. E. Lund, T. D. Randall, The establishment of resident memory B cells in the lung requires local antigen encounter. Nat. Immunol. 20, 97-108 (2019). doi:10.1038/s41590-0180260-6 Medline

33. N. M. Weisel, F. J. Weisel, D. L. Farber, L. A. Borghesi, Y. Shen, W. Ma, E. T. Luning Prak, M. J. Shlomchik, Comprehensive analyses of B-cell compartments across the human body reveal novel subsets and a gut-resident memory phenotype. Blood 136, 2774-2785 (2020). doi:10.1182/blood.2019002782 Medline

34. D. J. Carpenter, T. Granot, N. Matsuoka, T. Senda, B. V. Kumar, J. J. C. Thome, C. L. Gordon, M. Miron, J. Weiner, T. Connors, H. Lerner, A. Friedman, T. Kato, A. D. Griesemer, D. L. Farber, Human immunology studies using organ donors: Impact of clinical variations on immune parameters in tissues and circulation. Am. J. Transplant. 18, 74-88 (2018). doi:10.1111/ait.14434 Medline

35. J. J. Thome, N. Yudanin, Y. Ohmura, M. Kubota, B. Grinshpun, T. Sathaliyawala, T. Kato, H. Lerner, Y. Shen, D. L. Farber, Spatial map of human T cell compartmentalization and maintenance over decades of life. Cell 159, 814-828 (2014). doi:10.1016/j.cell.2014.10.026 Medline

36. C. Rydyznski Moderbacher, S. I. Ramirez, J. M. Dan, A. Grifoni, K. M. Hastie, D. Weiskopf, S. Belanger, R. K. Abbott, C. Kim, J. Choi, Y. Kato, E. G. Crotty, C. Kim, S. A. Rawlings, J. Mateus, L. P. V. Tse, A. Frazier, R. Baric, B. Peters, J. Greenbaum, E. Ollmann Saphire, D. M. Smith, A. Sette, S. Crotty, Antigen-Specific Adaptive Immunity to SARS-CoV-2 in Acute COVID-19 and Associations with Age and Disease Severity. Cell 183, 996-1012.e19 (2020). doi:10.1016/j.cell.2020.09.038 Medline

37. D. F. Gudbjartsson, G. L. Norddahl, P. Melsted, K. Gunnarsdottir, H. Holm, E. Eythorsson, A. O. Arnthorsson, D. Helgason, K. Bjarnadottir, R. F. Ingvarsson, B. Thorsteinsdottir, S. Kristjansdottir, K. Birgisdottir, A. M. Kristinsdottir, M. I. Sigurdsson, G. A. Arnadottir, E. V. Ivarsdottir, M. Andresdottir, F. Jonsson, A. B. Agustsdottir, J. Berglund, B. Eiriksdottir, R. Fridriksdottir, E. E. Gardarsdottir, M. Gottfredsson, O. S. Gretarsdottir, S. Gudmundsdottir, K. R. Gudmundsson, T. R. Gunnarsdottir, A. Gylfason, A. Helgason, B. O. Jensson, A. Jonasdottir, H. Jonsson, T. Kristjansson, K. G. Kristinsson, D. N. Magnusdottir, O. T. Magnusson, L. B. Olafsdottir, S. Rognvaldsson, L. le Roux, G. Sigmundsdottir, A. Sigurdsson, G. Sveinbjornsson, K. E. Sveinsdottir, M. Sveinsdottir, E. A. Thorarensen, B. Thorbjornsson, M. Thordardottir, J. Saemundsdottir, S. H. Kristjansson, K. S. Josefsdottir, G. Masson, G. Georgsson, M. Kristjansson, A. Moller, R. Palsson, T. Gudnason, U. Thorsteinsdottir, I. Jonsdottir, P. Sulem, K. Stefansson, Humoral Immune Response to SARS-CoV-2 in Iceland. N. Engl. J. Med. 383, 1724-1734 (2020). doi:10.1056/NEJMoa2026116 Medline

38. J. M. Dan, C. S. Lindestam Arlehamn, D. Weiskopf, R. da Silva Antunes, C. HavenarDaughton, S. M. Reiss, M. Brigger, M. Bothwell, A. Sette, S. Crotty, A CytokineIndependent Approach To Identify Antigen-Specific Human Germinal Center T Follicular Helper Cells and Rare Antigen-Specific CD4+ T Cells in Blood. J. Immunol. 197, 983-993 (2016). doi:10.4049/iimmunol.1600318 Medline

39. C. Havenar-Daughton, S. M. Reiss, D. G. Carnathan, J. E. Wu, K. Kendric, A. Torrents de la Peña, S. P. Kasturi, J. M. Dan, M. Bothwell, R. W. Sanders, B. Pulendran, G. Silvestri, S. Crotty, Cytokine-Independent Detection of AntigenSpecific Germinal Center T Follicular Helper Cells in Immunized Nonhuman Primates Using a Live Cell Activation-Induced Marker Technique. J. Immunol. 197, 994-1002 (2016). doi:10.4049/iimmunol.1600320 Medline

40. D. L. Farber, N. A. Yudanin, N. P. Restifo, Human memory T cells: Generation, compartmentalization and homeostasis. Nat. Rev. Immunol. 14, 24-35 (2014) doi:10.1038/nri3567 Medline

41. F. Sallusto, J. Geginat, A. Lanzavecchia, Central memory and effector memory T cell subsets: Function, generation, and maintenance. Annu. Rev. Immunol. 22 , 745-763 (2004). doi:10.1146/annurev.immunol.22.012703.104702 Medline

42. T. Sathaliyawala, M. Kubota, N. Yudanin, D. Turner, P. Camp, J. J. Thome, K. L. Bickham, H. Lerner, M. Goldstein, M. Sykes, T. Kato, D. L. Farber, Distribution and compartmentalization of human circulating and tissue-resident memory $T$ cell subsets. Immunity 38, 187-197 (2013). doi:10.1016/j.immuni.2012.09.020 Medline

43. J. Sun, R. Madan, C. L. Karp, T. J. Braciale, Effector T cells control lung inflammation during acute influenza virus infection by producing IL-10. Nat. Med. 15, 277-284 (2009). doi:10.1038/nm.1929 Medline

44. N. R. Mathew, J. K. Jayanthan, I. V. Smirnov, J. L. Robinson, H. Axelsson, S. S. Nakka, A. Emmanouilidi, P. Czarnewski, W. T. Yewdell, K. Schön, C. LebreroFernández, V. Bernasconi, W. Rodin, A. M. Harandi, N. Lycke, N. Borcherding, J. W. Yewdell, V. Greiff, M. Bemark, D. Angeletti, Single-cell BCR and transcriptome analysis after influenza infection reveals spatiotemporal dynamics of antigenspecific B cells. Cell Rep. 35, 109286 (2021). doi:10.1016/j.celrep.2021.109286 Medline 
45. G. D. Victora, M. C. Nussenzweig, Germinal centers. Annu. Rev. Immunol. 30, 429457 (2012). doi:10.1146/annurev-immunol-020711-075032 Medline

46. J. S. Turner, W. Kim, E. Kalaidina, C. W. Goss, A. M. Rauseo, A. J. Schmitz, L. Hansen, A. Haile, M. K. Klebert, I. Pusic, J. A. O'Halloran, R. M. Presti, A. H. Ellebedy, SARS-CoV-2 infection induces long-lived bone marrow plasma cells in humans. Nature 595, 421-425 (2021). doi:10.1038/s41586-021-03647-4 Medline

47. S. Boppana, K. Qin, J. K. Files, R. M. Russell, R. Stoltz, F. Bibollet-Ruche, A. Bansal, N. Erdmann, B. H. Hahn, P. A. Goepfert, SARS-CoV-2-specific circulating T follicular helper cells correlate with neutralizing antibodies and increase during early convalescence. PLOS Pathog. 17, e1009761 (2021). doi:10.1371/journal.ppat.1009761 Medline

48. A. Sette, S. Crotty, Adaptive immunity to SARS-CoV-2 and COVID-19. Cell 184 861-880 (2021). doi:10.1016/i.cell.2021.01.007 Medline

49. K. Basso, R. Dalla-Favera, Roles of BCL6 in normal and transformed germinal center B cells. Immunol. Rev. 247, 172-183 (2012). doi:10.1111/i.1600065X.2012.01112.x Medline

50. S. Crotty, Follicular helper CD4 T cells (TFH). Annu. Rev. Immunol. 29, 621-663 (2011). doi:10.1146/annurev-immunol-031210-101400 Medline

51. Y. Xu, X. Li, B. Zhu, H. Liang, C. Fang, Y. Gong, Q. Guo, X. Sun, D. Zhao, J. Shen, H. Zhang, H. Liu, H. Xia, J. Tang, K. Zhang, S. Gong, Characteristics of pediatric SARSCoV-2 infection and potential evidence for persistent fecal viral shedding. Nat. Med. 26, 502-505 (2020). doi:10.1038/s41591-020-0817-4 Medline

52. G. Breton, P. Mendoza, T. Hägglöf, T. Y. Oliveira, D. Schaefer-Babajew, C. Gaebler, M. Turroja, A. Hurley, M. Caskey, M. C. Nussenzweig, Persistent cellular immunity to SARS-CoV-2 infection. J. Exp. Med. 218, e20202515 (2021). doi:10.1084/jem.20202515 Medline

53. N. Kaneko, H. H. Kuo, J. Boucau, J. R. Farmer, H. Allard-Chamard, V. S. Mahajan, A. Piechocka-Trocha, K. Lefteri, M. Osborn, J. Bals, Y. C. Bartsch, N. Bonheur, T. M. Caradonna, J. Chevalier, F. Chowdhury, T. J. Diefenbach, K. Einkauf, J. Fallon, J. Feldman, K. K. Finn, P. Garcia-Broncano, C. A. Hartana, B. M. Hauser, C. Jiang, P. Kaplonek, M. Karpell, E. C. Koscher, X. Lian, H. Liu, J. Liu, N. L. Ly, A. R. Michell, Y. Rassadkina, K. Seiger, L. Sessa, S. Shin, N. Singh, W. Sun, X. Sun, H. J. Ticheli, M. T. Waring, A. L. Zhu, G. Alter, J. Z. Li, D. Lingwood, A. G. Schmidt, M. Lichterfeld, B. D. Walker, X. G. Yu, R. F. Padera Jr., S. Pillai; Massachusetts Consortium on Pathogen Readiness Specimen Working Group, Loss of Bcl-6-Expressing T Follicular Helper Cells and Germinal Centers in COVID-19. Cell 183, 143-157.e13 (2020). doi:10.1016/i.cell.2020.08.025 Medline

54. M. Sakharkar, C. G. Rappazzo, W. F. Wieland-Alter, C. L. Hsieh, D. Wrapp, E. S. Esterman, C. I. Kaku, A. Z. Wec, J. C. Geoghegan, J. S. McLellan, R. I. Connor, P. F. Wright, L. M. Walker, Prolonged evolution of the human B cell response to SARSCoV-2 infection. Sci. Immunol. 6, eabg6916 (2021). doi:10.1126/sciimmunol.abg6916 Medline

55. T. Granot, T. Senda, D. J. Carpenter, N. Matsuoka, J. Weiner, C. L. Gordon, M. Miron, B. V. Kumar, A. Griesemer, S. H. Ho, H. Lerner, J. J. C. Thome, T. Connors, B. Reizis, D. L. Farber, Dendritic Cells Display Subset and Tissue-Specific Maturation Dynamics over Human Life. Immunity 46, 504-515 (2017). doi:10.1016/i.immuni.2017.02.019 Medline

56. B. V. Kumar, R. Kratchmarov, M. Miron, D. J. Carpenter, T. Senda, H. Lerner, A. Friedman, S. L. Reiner, D. L. Farber, Functional heterogeneity of human tissueresident memory T cells based on dye efflux capacities. JCl Insight 3, e123568 (2018). doi:10.1172/ici.insight.123568 Medline

57. M. Miron, B. V. Kumar, W. Meng, T. Granot, D. J. Carpenter, T. Senda, D. Chen, A. M. Rosenfeld, B. Zhang, H. Lerner, A. L. Friedman, U. Hershberg, Y. Shen, A. Rahman, E. T. Luning Prak, D. L. Farber, Human lymph nodes maintain TCF-1hi memory T cells with high functional potential and clonal diversity throughout life. J. Immunol. 201, 2132-2140 (2018). doi:10.4049/jimmunol.1800716 Medline

58. T. Senda, P. Dogra, T. Granot, K. Furuhashi, M. E. Snyder, D. J. Carpenter, P. A. Szabo, P. Thapa, M. Miron, D. L. Farber, Microanatomical dissection of human intestinal T-cell immunity reveals site-specific changes in gut-associated lymphoid tissues over life. Mucosal Immunol. 12, 378-389 (2019). doi:10.1038/s41385-018-0110-8 Medline

59. P. Dogra, C. Rancan, W. Ma, M. Toth, T. Senda, D. J. Carpenter, M. Kubota, R. Matsumoto, P. Thapa, P. A. Szabo, M. M. Li Poon, J. Li, J. Arakawa-Hoyt, Y. Shen, L. Fong, L. L. Lanier, D. L. Farber, Tissue Determinants of Human NK Cell Development, Function, and Residence. Cell 180, 749-763.e13 (2020). doi:10.1016/i.cell.2020.01.022 Medline

60. A. Pugliese, M. Yang, I. Kusmarteva, T. Heiple, F. Vendrame, C. Wasserfall, P. Rowe, J. M. Moraski, S. Ball, L. Jebson, D. A. Schatz, R. Gianani, G. W. Burke, C. Nierras, T. Staeva, J. S. Kaddis, M. Campbell-Thompson, M. A. Atkinson, The Juvenile Diabetes Research Foundation Network for Pancreatic Organ Donors with Diabetes (nPOD) Program: Goals, operational model and emerging findings. Pediatr. Diabetes 15, 1-9 (2014). doi:10.1111/pedi.12097 Medline

61. D. Weiskopf, K. S. Schmitz, M. P. Raadsen, A. Grifoni, N. M. A. Okba, H. Endeman, J. P. C. van den Akker, R. Molenkamp, M. P. G. Koopmans, E. C. M. van Gorp, B. L. Haagmans, R. L. de Swart, A. Sette, R. D. de Vries, Phenotype and kinetics of SARS-CoV-2-specific T cells in COVID-19 patients with acute respiratory distress syndrome. Sci. Immunol. 5, eabd2071 (2020). doi:10.1126/sciimmunolabd2071 Medline

62. S. Reiss, A. E. Baxter, K. M. Cirelli, J. M. Dan, A. Morou, A. Daigneault, N. Brassard, G. Silvestri, J. P. Routy, C. Havenar-Daughton, S. Crotty, D. E. Kaufmann, Comparative analysis of activation induced marker (AIM) assays for sensitive identification of antigen-specific CD4 T cells. PLOS ONE 12, e0186998 (2017). doi:10.1371/journal.pone.0186998 Medline

63. F. Pedregosa, G. Varoquaux, A. Gramfort, V. Michel, B. Thirion, O. Grisel, M. Blondel, P. Prettenhofer, R. Weiss, V. Dubourg, J. Vanderplas, A. Passos, D. Cournapeau, M. Brucher, M. Perrot, E. Duchesnay, Scikit-learn: Machine Learning in Python. JMLR 12, 2825-2830 (2011).

64. W. L. Waskom, seaborn: Statistical data visualization. J. Open Source Softw. 6 , 3021 (2021). doi:10.21105/joss.03021

65. T. Wei, V. Simko, R package "corrplot": Visualization of a correlation matrix. (Version 0.89). (2021)

66. J. D. Hunter, Matplotlib: A 2D Graphics Environment. Comput. Sci. Eng. 9, 90-95 (2007). doi:10.1109/MCSE.2007.55

Acknowledgments: Funding: This work was supported by National Institutes of Health grants Al100119,Al128949 (Human Immunology Project Consortium) and Al106697 (to DLF), Al142742 (Cooperative Centers for Human Immunology) (to AS, SC), National Institutes of Health grant contract Number 75N9301900065 (DW, AS), grant K23Al141686 (TJC), and a Helmsley Charitable Trust grant (TMB, DLF). The CCTI Flow Cytometry Core was supported by NIH S10RR027050 and S100D020056. P.D. was supported by a Cancer Research Institute (CRI) Irvington Postdoctoral Fellowship; N.L, was supported by a National Science Foundation Graduate Research Fellowship Program (NSFGRFP); P.S. was supported by the Canadian Institutes of Health Research (CIHR) Fellowship. Author contributions: Conceptualization: MMLP, KR, YK, DLF, SC. Methodology: MMLP, KR, YK, NIB, ZZ. Investigation: MMLP, KR, YK, NIB, ZZ. Visualization: MMLP, KR, YK. Resources: AS, AG, DW, MK, RM, KMH, EOS, MAB, TMB, TJC, BBU, NL, PAS, PD, YSL, JIG, MCB. Supervision: DLF, SC. Writing original draft: MMLP, KR, YK, DLF, SC. Writing - review and editing: MMLP, KR, YK, DLF, SC. Project administration: DLF, SC, SBW. Funding acquisition - DLF, SC, AS. Competing interests: A.S. is a consultant for Gritstone, Flow Pharma, Merck, Epitogenesis, Gilead, and Avalia. S.C has consulted for Avalia, Roche and GSK. L.J.I. has filed for patent protection for various aspects of T cell epitope and vaccine design work. All remaining authors declare no competing interests. Data and materials availability: All data needed to evaluate the conclusions of the paper are available in the paper or the Supplementary Materials. This work is licensed under a Creative Commons Attribution 4.0 International (CC BY 4.0) license, which permits unrestricted use, distribution, and reproduction in any medium, provided the original work is properly cited. To view a copy of this license, visit https://creativecommons.org/licenses/by/4.0/. This license does not apply to figures/photos/artwork or other content included in the article that is credited to a third party; obtain authorization from the rights holder before using such material.

Submitted 12 August 2021

Accepted 4 October 2021

Published First Release 7 October 2021

10.1126/sciimmunol.abl9105 

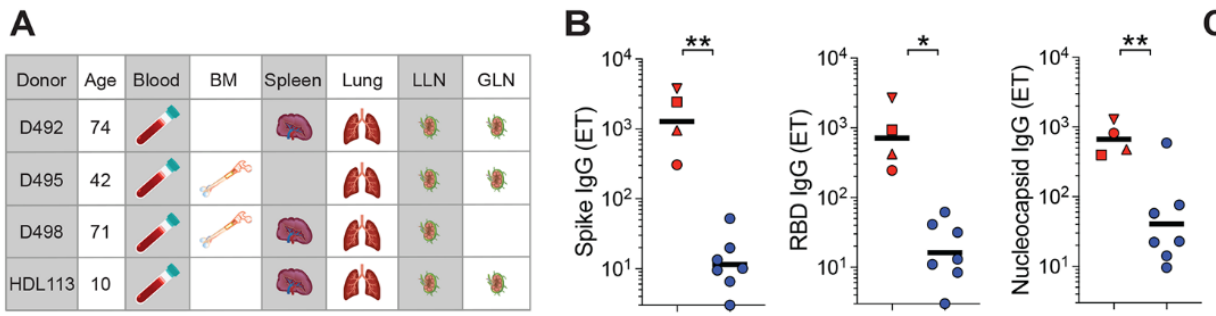

D

CD4 $\mathrm{AIM}^{+}\left(\mathrm{CD} 40 \mathrm{~L}^{+} 4-1 \mathrm{BB}^{+}, \mathrm{OX}^{+} 40^{+} 4-1 \mathrm{BB}^{+}, \mathrm{CD}^{2} 4 \mathrm{~L}^{+} \mathrm{OX} 40^{+}\right)-\mathrm{D} 498$
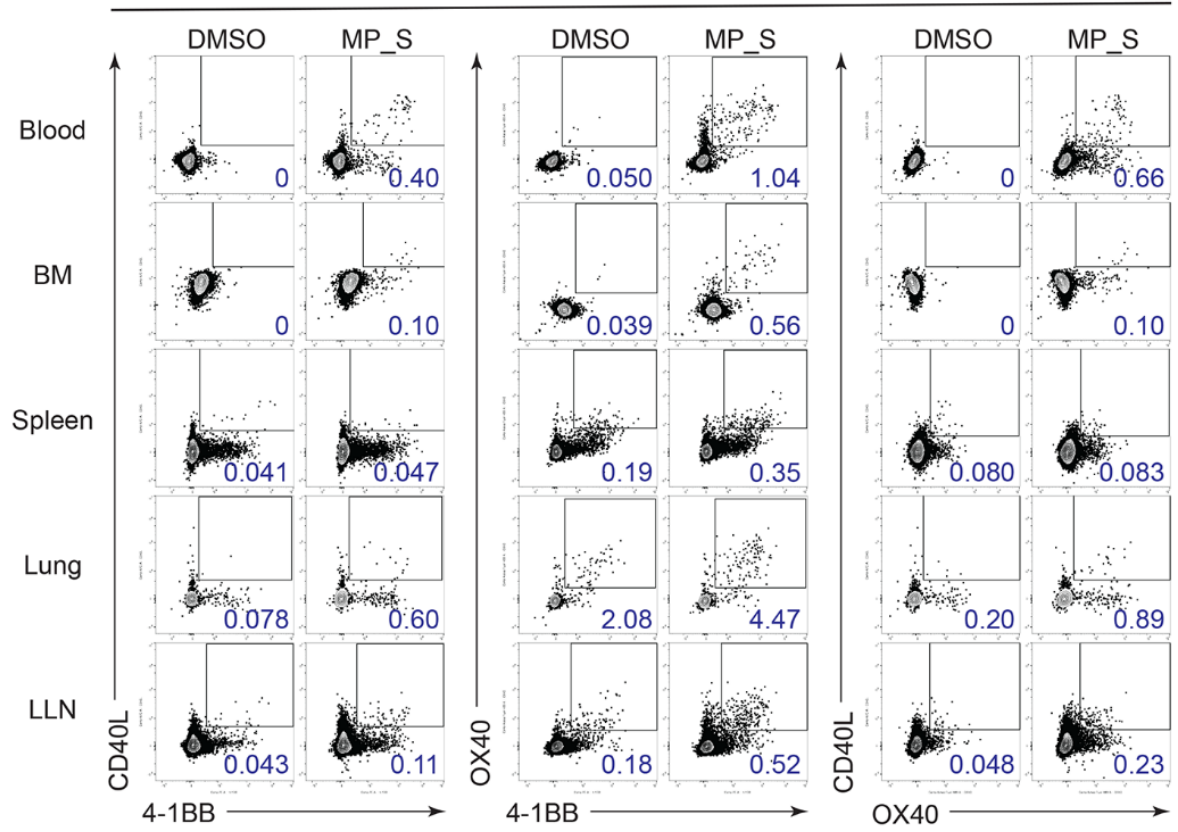

$\mathbf{F}$

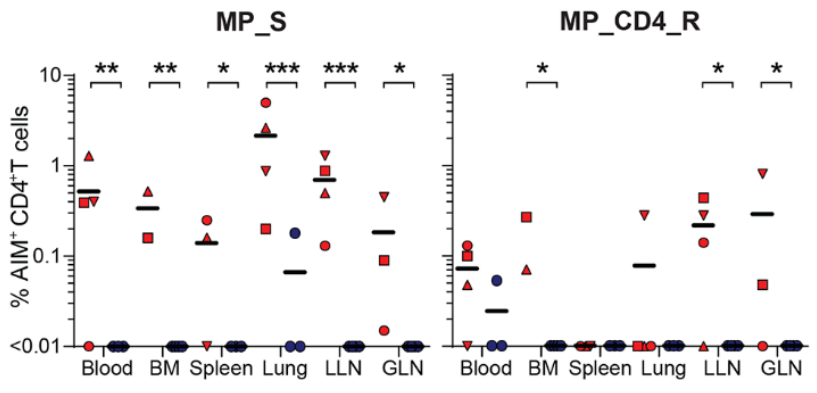

H

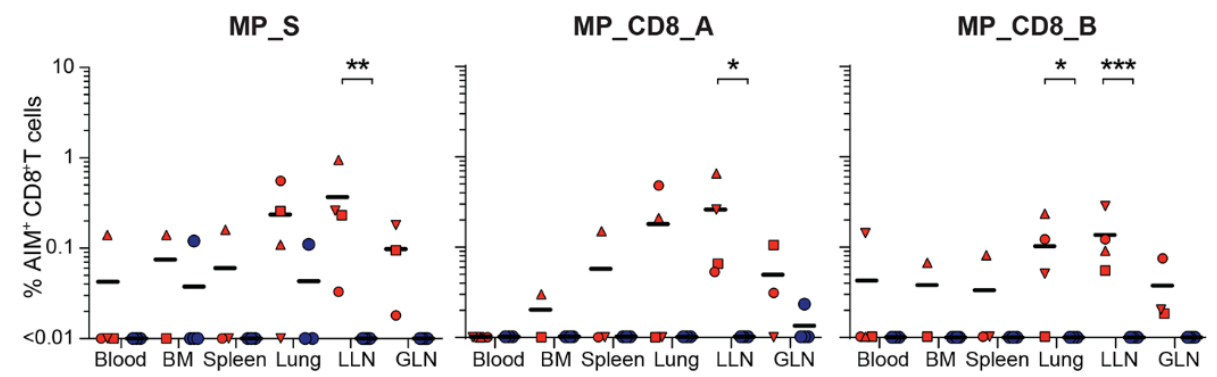

E

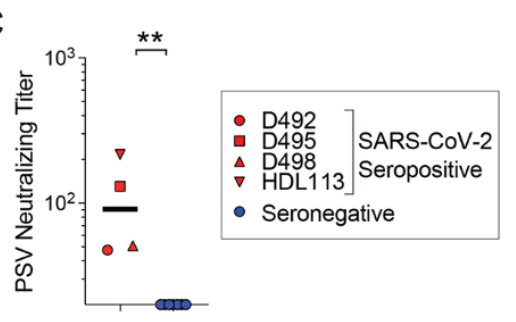
$\frac{\mathrm{CD} 8 \mathrm{AlM}^{+}\left(4-1 \mathrm{BB}^{+} \mathrm{CD} 25^{+}\right)-\mathrm{D} 495}{\text { DMSO }}$

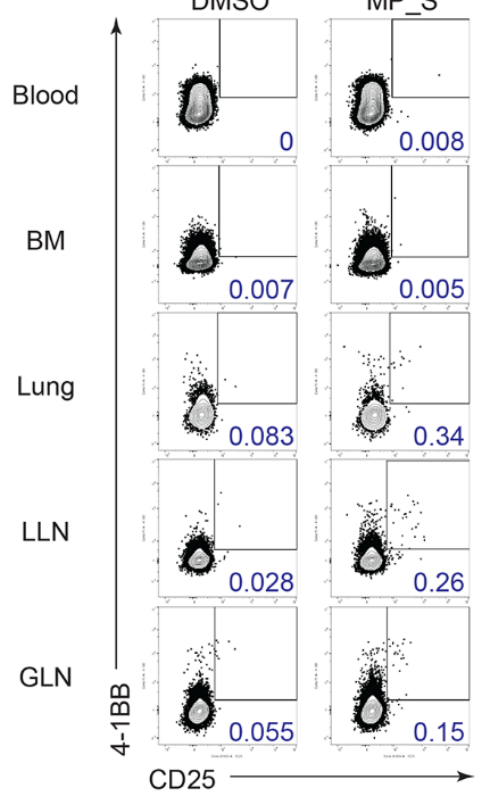

G
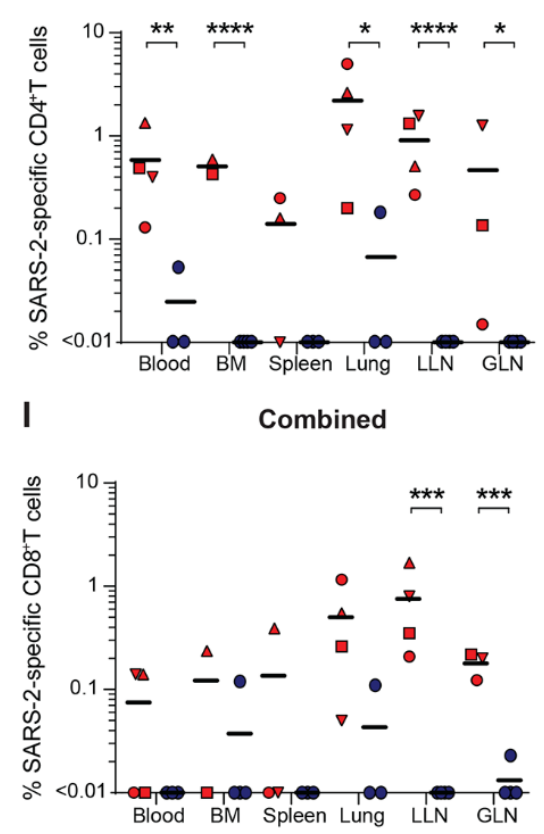
Fig. 1. SARS-CoV-2-specific CD4 ${ }^{+}$and $C D 8^{+}$T cells in blood and tissues of previously infected organ donors. (A) SARS-CoV-2 seropositive donors and tissues used from each donor for this study. (B) Anti-SARS-CoV-2 antibody reactivities for seropositive and seronegative donors. Graphs show endpoint titers (ET) of IgG specific for SARS-CoV-2 Spike, RBD, and Nucleocapsid. (C) SARS-CoV-2 Spike pseudovirus (PSV) neutralizing titers for seropositive and seronegative donors. Serology statistical analyses were performed using Mann-Whitney $U$ test. ${ }^{*} \mathrm{p} \leq 0.05 ;{ }^{* *} \mathrm{p} \leq 0.01 ;{ }^{* * *} \mathrm{p} \leq 0.001 ;{ }^{* * *} \mathrm{p} \leq 0.0001$. (D) Identification of SARS-CoV-2-specific CD4 ${ }^{+} \mathrm{T}$ cells using the activation-induced marker (AIM) assay. Mononuclear cells isolated from blood, bone marrow (BM), spleen, lung, and lung-associated lymph node (LLN) were stimulated with SARS-CoV-2 peptide pools (See Materials and Methods) and responding CD4 ${ }^{+} T$ cells were identified based on induction of OX40, 4-1BB, and CD4OL as shown in representative flow cytometry plots from D498 reactive to MP_S. SARS-CoV-2-specific $\mathrm{CD}^{+} \mathrm{T}$ cells were defined based on combined gates $\mathrm{CD}^{-} \mathrm{OL}{ }^{+} 4-1 \mathrm{BB}^{+}$(left), $\mathrm{OX}^{-} 40^{+} 4-1 \mathrm{BB}^{+}$(middle), or $\mathrm{CD} 4 \mathrm{~L}^{+} \mathrm{OX} 4 \mathrm{O}^{+}$(right) of total $\mathrm{CD} 4^{+} \mathrm{T}$ cells for each stimulation condition and tissue site (see fig. S1 for gating strategy). (E) AIM assay for detection of SARS-CoV-2-specific CD8 ${ }^{+}$T cells in blood, BM, lung, LLN, and gutassociated lymph node (GLN), showing induction of 4-1BB and CD25 in representative flow cytometry plots from D495 reactive to MP_S. AIM ${ }^{+}$CD8 T cells were defined based on frequency $4-1 B B^{+} C D 25^{+}$from total CD8 ${ }^{+}$ T cells for each stimulation condition and tissue site (see fig. S1 for gating strategy). (F) SARS-CoV-2 epitopespecific $C D 4^{+} T$ cells identified following stimulation with MP_S (left) and MP_CD4_R (right) peptide megapools (MPs) from indicated tissues sites of seropositive and seronegative donors. (G) Total SARS-CoV-2-specific $\mathrm{CD}^{+} \mathrm{T}$ cells in each site from individual donors based on responses to all epitopes. (H) SARS-CoV-2 epitopespecific CD8 ${ }^{+} T$ cells identified following stimulation with MP_S (left), MP_CD8_A (middle), and MP_CD8_B (right) peptide MPs from indicated sites of seropositive and seronegative donors. (I) Total SARS-CoV-2-specific CD8 ${ }^{+} \mathrm{T}$ cells in each site from individual donors based on compiled responses to all epitopes. $\mathrm{n}=4 \mathrm{SARS}-\mathrm{CoV}-2$ seropositive subjects ( $n=4$ for blood, lung, $L L N ; n=3$ for spleen and $G L N ; n=2$ for $B M$ ). $n=10$ for seronegative subjects ( $n=4$ for BM, LLN, and GLN; $n=3$ for blood, spleen, and lung). Statistical analysis was performed using one-way ANOVA, corrected for multiple comparisons by false discovery rate (FDR) using two-stage linear stepup procedure of Benjamini, Krieger, and Yekutieli. ${ }^{*} \mathrm{q} \leq 0.05 ;{ }^{*} \mathrm{q} \leq 0.01 ;{ }^{* *} \mathrm{q} \leq 0.001 ;{ }^{* * * *} \mathrm{q} \leq 0.0001$. Datasets were log-transformed before statistical analysis. ET, endpoint titer; RBD, receptor-binding domain; PSV, pseudovirus; AIM, activation-induced marker; BM, bone marrow; LLN, lung-associated lymph node; GLN, gut-associated lymph node. 
A

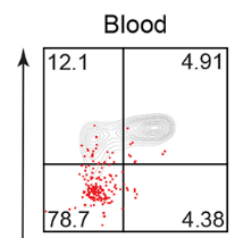

- SARS-2-specific

ำ

\begin{abstract}
CD45RA
\end{abstract}
B

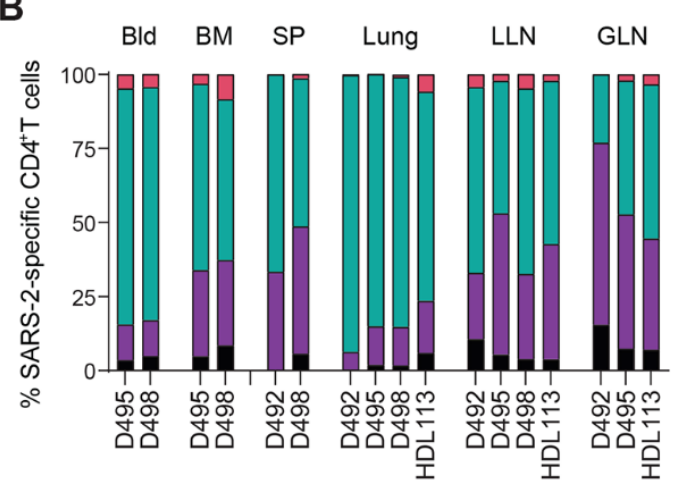

D

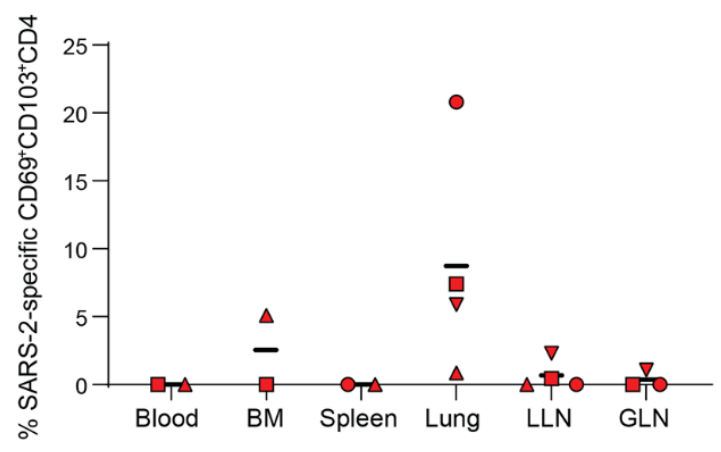

C

E
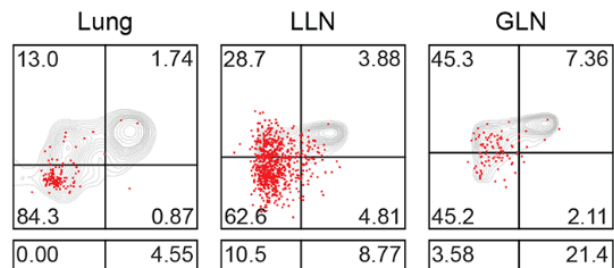

CD4

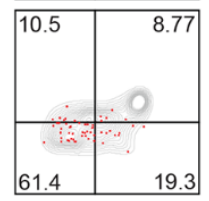

$19.3[53.6$

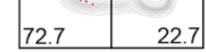

\begin{tabular}{|l|l|}
\hline 72.7 & 22.7 \\
\hline
\end{tabular}

C
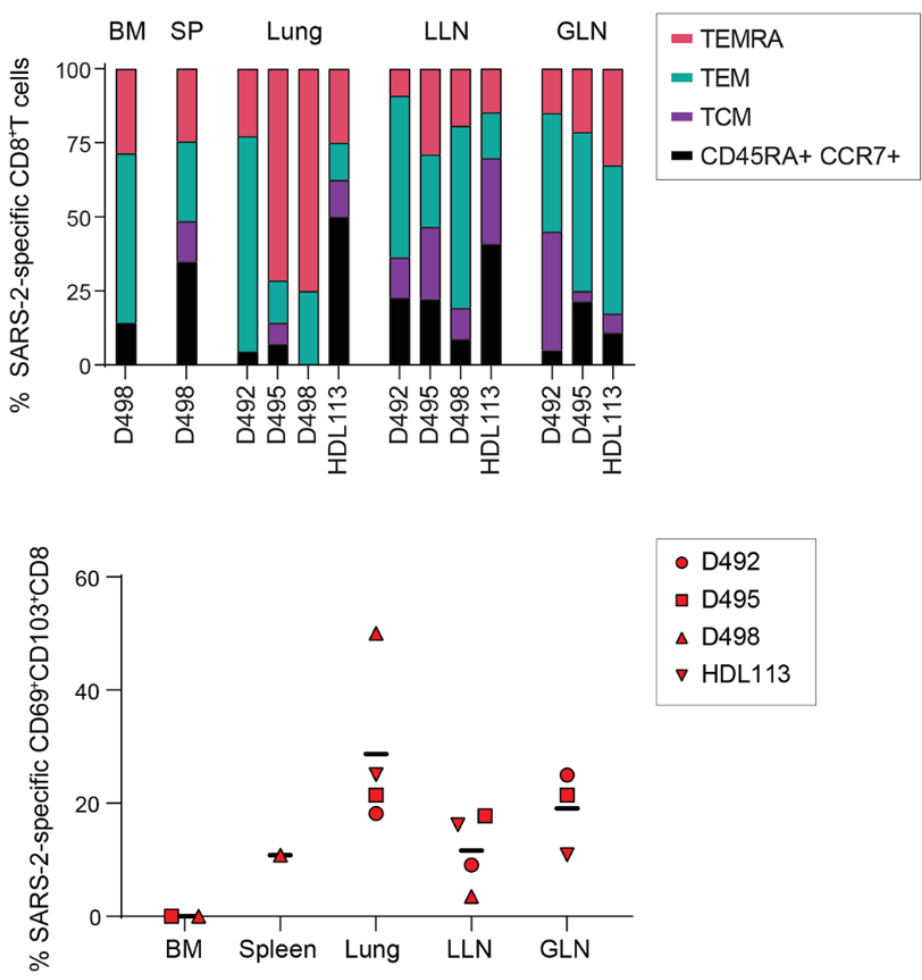

Fig. 2. SARS-CoV-2-specific T cells are maintained as memory subsets in diverse tissues of seropositive donors. (A) Subset phenotypes of total (grey contour) and SARS-CoV-2-specific (red dots) CD4+ (top row) and CD8 ${ }^{+}$(bottom row) T cells based on CD45RA and CCR7 expression (CD45RA ${ }^{+} \mathrm{CCR}^{+}{ }^{+}$; CD45RA-CCR7 ${ }^{+}$, TCM; CD45RA CCR7 ${ }^{-}$, TEM; CD45RA ${ }^{+}$CCR7 ${ }^{-}$, TEMRA) shown in representative flow cytometry plots. (B) T cell subset delineation of SARS-CoV2-specific CD4 ${ }^{+} T$ cells in blood and indicated tissues of seropositive organ donors. (C) $T$ cell memory subset delineation of SARS-CoV-2-specific CD8 ${ }^{+} \mathrm{T}$ cells in blood and indicated tissues of seropositive organ donors. (D) Expression of tissue residency markers CD69 and CD103 by SARS-CoV-2-specific CD4 ${ }^{+}$T cells in indicated sites of seropositive donors. (E) Expression of tissue residency markers CD69 and CD103 by SARS-CoV-2-specific CD8 ${ }^{+}$T cells in indicated sites of seropositive donors. Memory subset differentiation and residency marker analysis was conducted on tissue sites for which number of SARS-CoV-2-specific T cells was $\geq 5$ based on AIM assays. SARSCoV-2-specific CD8 ${ }^{+} \mathrm{T}$ cells in the blood were not detected above this threshold. $\mathrm{n}=4$ SARS-CoV-2 seropositive subjects ( $n=4$ for blood, lung, $L L N ; n=3$ for spleen and $G L N ; n=2$ for $B M$ ). $n=10$ for seronegative subjects ( $n=4$ for $B M$, $\mathrm{LLN}$, and GLN; $\mathrm{n}=3$ for blood, spleen, and lung). Statistical analysis was performed using one-way ANOVA, corrected for multiple comparisons by FDR using two-stage linear step-up procedure of Benjamini, Krieger, and Yekutieli. * $\mathrm{q} \leq$ $0.05 ;{ }^{* *} \mathrm{q} \leq 0.01 ;{ }^{* *} \mathrm{q} \leq 0.001 ;{ }^{* * *} \mathrm{q} \leq 0.0001$. Datasets were log-transformed before statistical analysis. SARS-2, SARS-CoV-2; TCM, central memory T cell; TEM, effector memory T cell, TEMRA, terminally-differentiated effector T cell; Bld, blood; BM, bone marrow; SP, spleen; LLN, lung-associated lymph node; GLN, gut-associated lymph node. 
A

Concentration (normalized to DMSO; max absolute scaled per column) $\begin{array}{lllll}-0.8 & -0.4 & 0.0 & 0.4 & 0.8\end{array}$

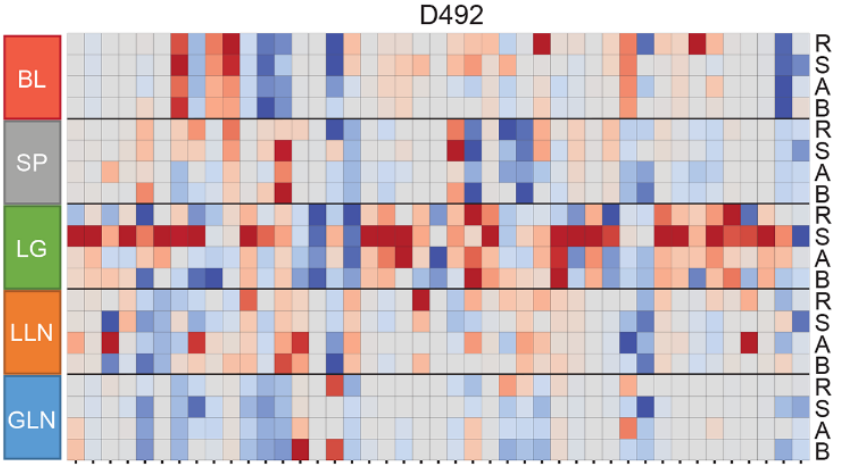

D495

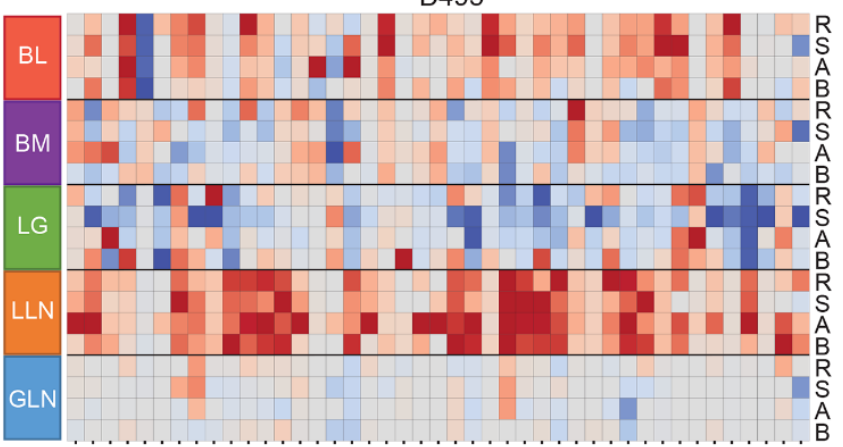

D498

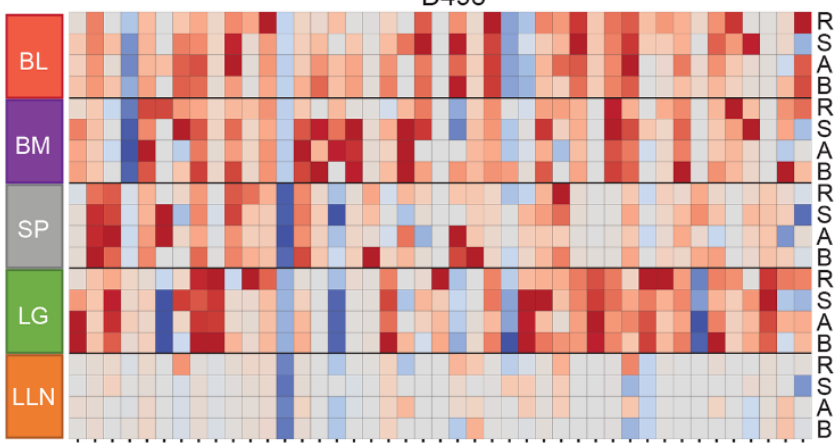

HDL113

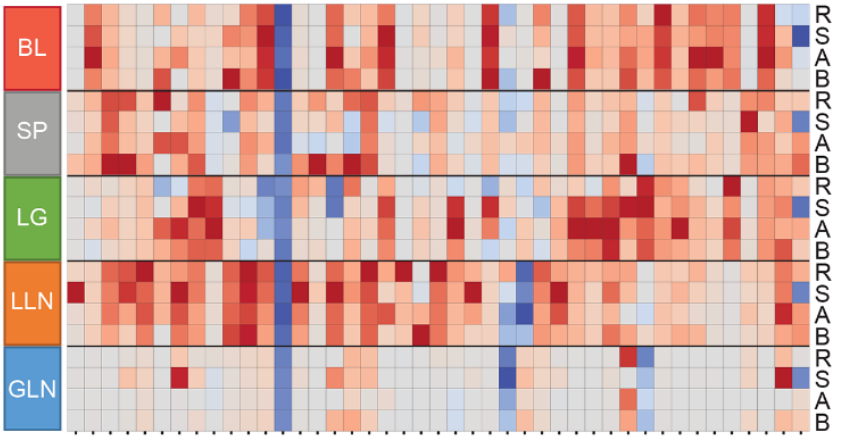

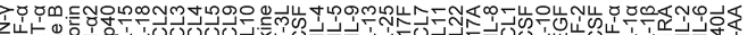

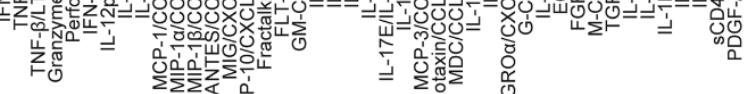

B

- D492 a D495 $\Delta$ D498 $\nabla$ HDL113

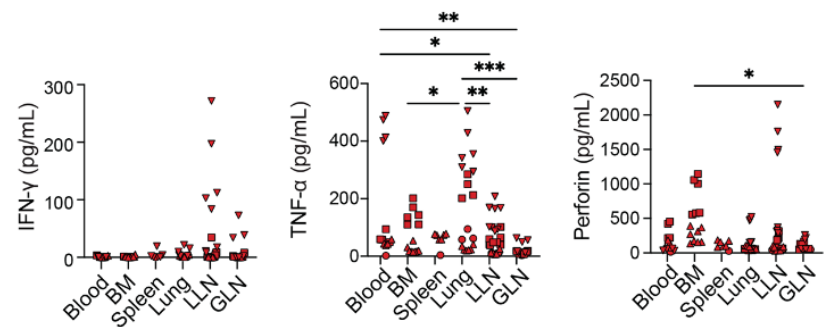

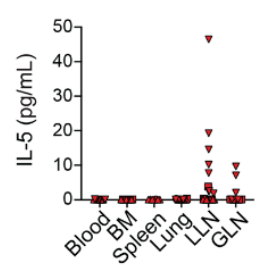
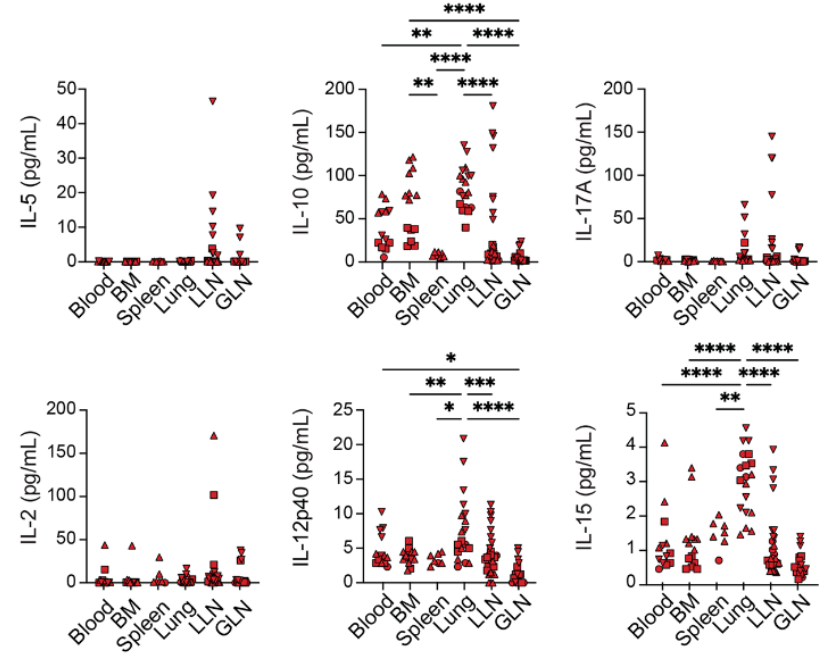

C
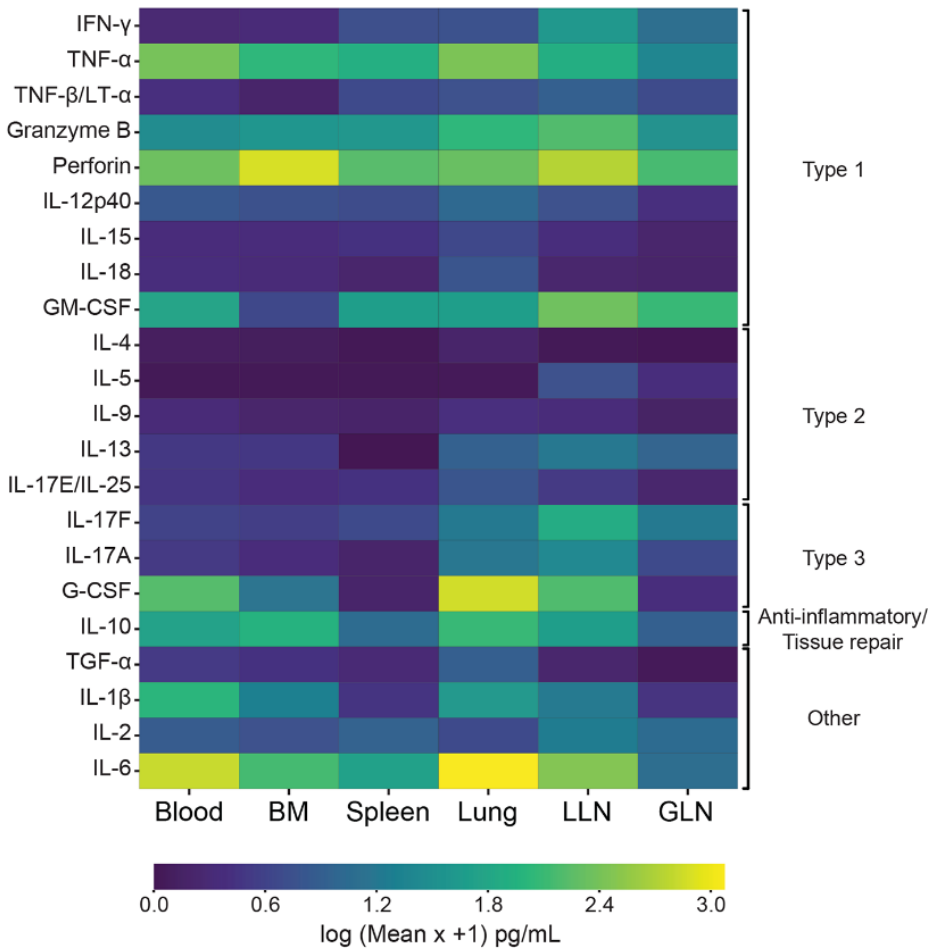
Fig. 3. Heterogeneity and tissue specificity of functional responses to SARS-CoV-2 epitopes. (A) Profiles of immune mediators produced for multiple tissue sites within SARS-CoV-2 seropositive donors following stimulation with peptide MPs MP_S (S), MP_CD4_R (R), MP_CD8_A (A), and MP_CD8_B (B), shown as a heatmap. The color intensity of each cell represents DMSO-background-subtracted analyte concentration (max absolute scaled per row) within each donor (See Materials and Methods). (B) Concentration of indicated immune mediators measured within supernatants from in vitro stimulations of blood, BM, spleen, lung, LLN, and GLN mononuclear cells with SARS-CoV-2 MPs for which SARS-CoV-2-specific T cells were identified based on DMSO-background-subtracted frequencies of $\mathrm{AIM}^{+} \mathrm{CD} 4^{+}$and $\mathrm{CD} 8^{+} \mathrm{T}$ cells. Statistical analysis was performed using one-way ANOVA, corrected for multiple comparisons by Tukey's multiple comparisons test. ${ }^{*}, p \leq 0.05 ;{ }^{*}, p \leq 0.01 ;{ }^{* *}, p \leq 0.001,{ }^{* * * *}, p \leq 0.0001$. (C) Immune mediator milieu for each site. Heatmap showing log (Mean $x+1) \mathrm{pg} / \mathrm{mL}$ levels of immune mediators averaged across donors and stimulation conditions for each tissue site, derived from samples for which significant frequencies of SARS-CoV-2-specific T cells were identified above background in Fig. 1. BL, blood; BM, bone marrow; SP, spleen; LG, lung; LLN, lung-associated lymph node; GLN, gut-associated lymph node. 
A
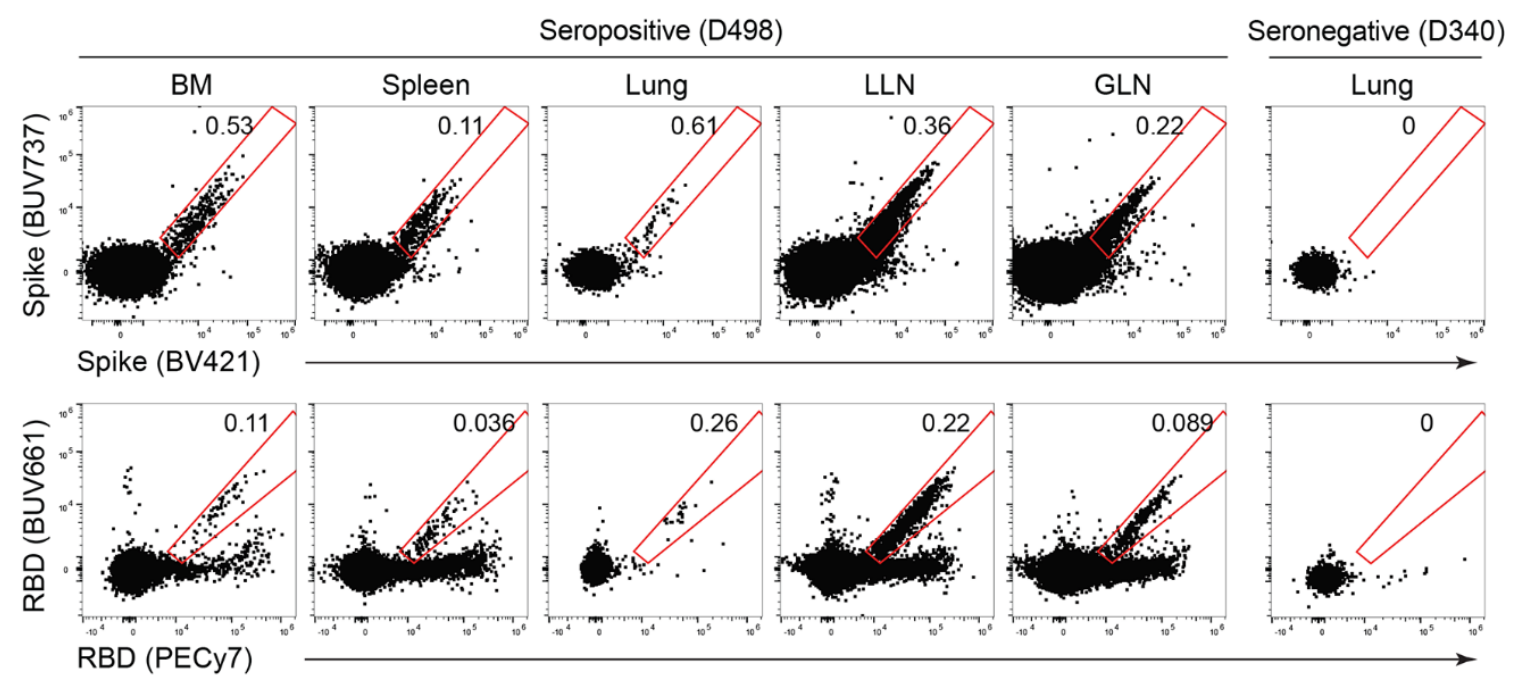

B

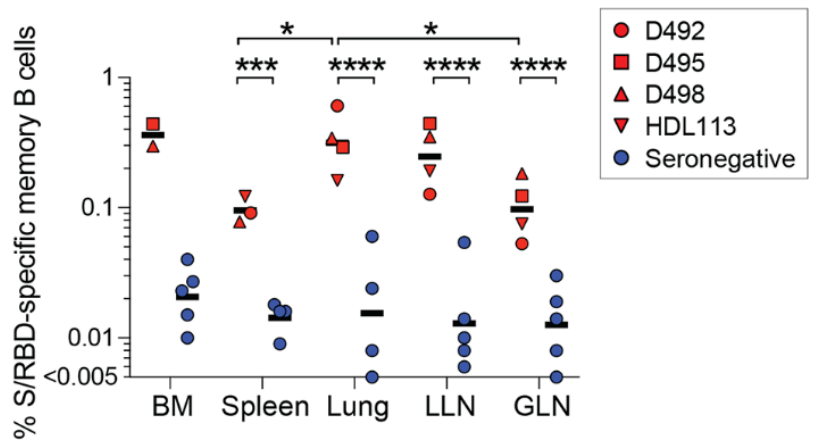

D

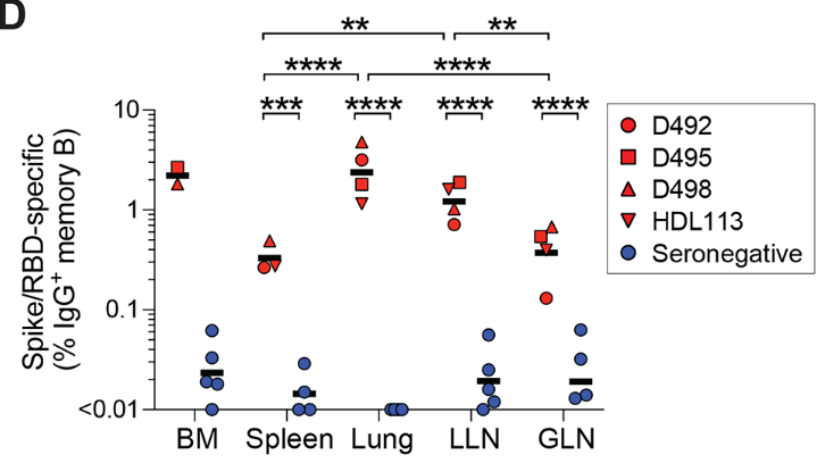

C

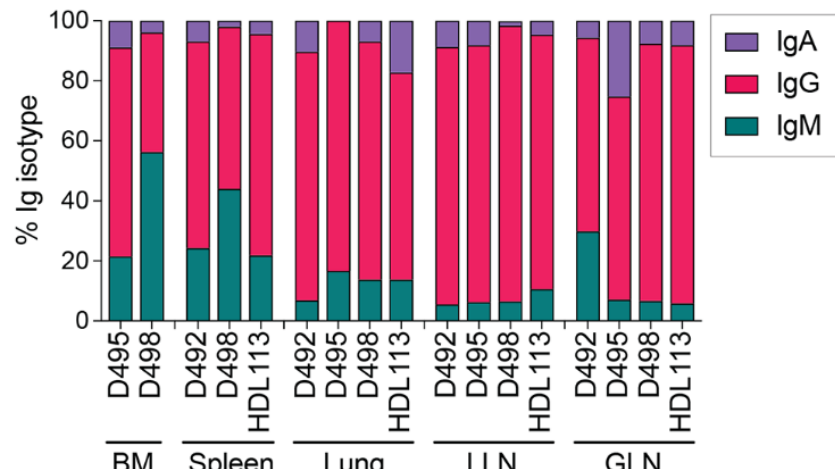

$\mathbf{F}$

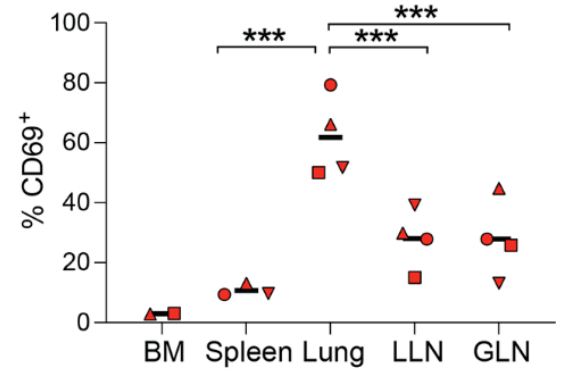

$\mathbf{E}$

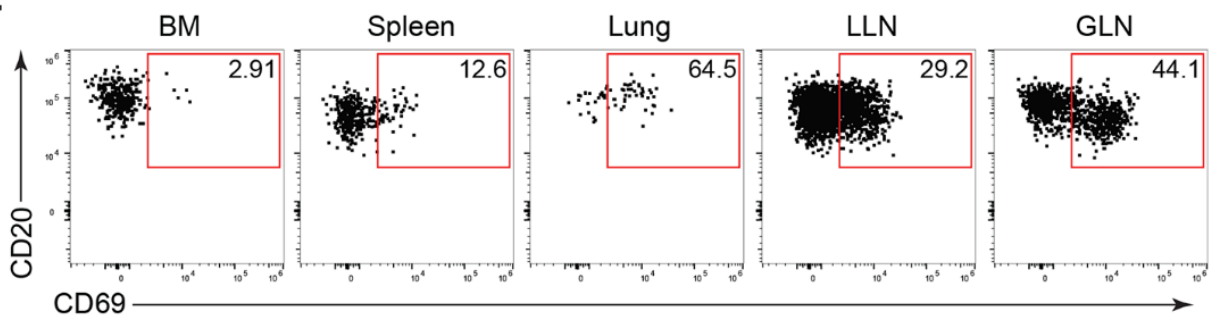


Fig. 4. SARS-CoV-2-specific memory $B$ cells in tissues. (A) Representative flow cytometry plots showing staining patterns of probes for SARS-CoV-2 Spike (upper panel) and RBD (lower panel) on memory B cells, defined here as $C^{2} 19^{+} C D 20^{+}$IgD non-GC B cells (see fig. S5A for gating). Memory B cells in BM, spleen, lung, LLN, and GLN from a SARS-CoV-2 Spike seropositive subject (D498) and memory B cells in lung from a seronegative subject (D340). Percentages are indicated. (B) SARS-CoV-2-specific memory B cells in tissues. Graph shows frequency of memory B cells specific to Spike and/or RBD (S/RBD) in indicated sites expressed as a percentage of $\mathrm{CD} 19^{+} \mathrm{CD} 2 \mathrm{O}^{+}$total B cells. (C) Fraction of SARS-CoV-2 S/RBD-specific memory B cells that belong to indicated lg isotypes. (D) Frequency (percentage) of $/ g G^{+}$memory B cells that are specific to S/RBD. (E) Representative flow cytometry plots showing CD69 expression on memory B cells specific to S/RBD. Percentages are indicated. (F) Frequency (percentage) of SARS-CoV-2 S/RBD-specific memory B cells that are CD69+. $n=4$ Seropositive subjects ( $n=4$ for lung, LLN, GLN; $n=3$ for spleen; $n=2$ for BM). $n=7$ Seronegative donors ( $n=4$ for lung, spleen; $n=5$ for LLN, GLN, BM). Statistical analysis was performed using one-way ANOVA, corrected for multiple comparisons by FDR using two-stage linear step-up procedure of Benjamini, Krieger, and Yekutieli. ${ }^{*} \mathrm{q} \leq 0.05$; ${ }^{* *} \mathrm{q} \leq 0.01 ;{ }^{* * *} \mathrm{q} \leq 0.001 ;{ }^{* * *} \mathrm{q} \leq 0.0001$. For (B) and (D), datasets were logtransformed before statistical analysis. S/RBD, SARS-CoV-2 Spike and/or RBD; RBD, receptor-binding domain; BM, bone marrow; LLN, lung-associated lymph node; GLN, gut-associated lymph node. 

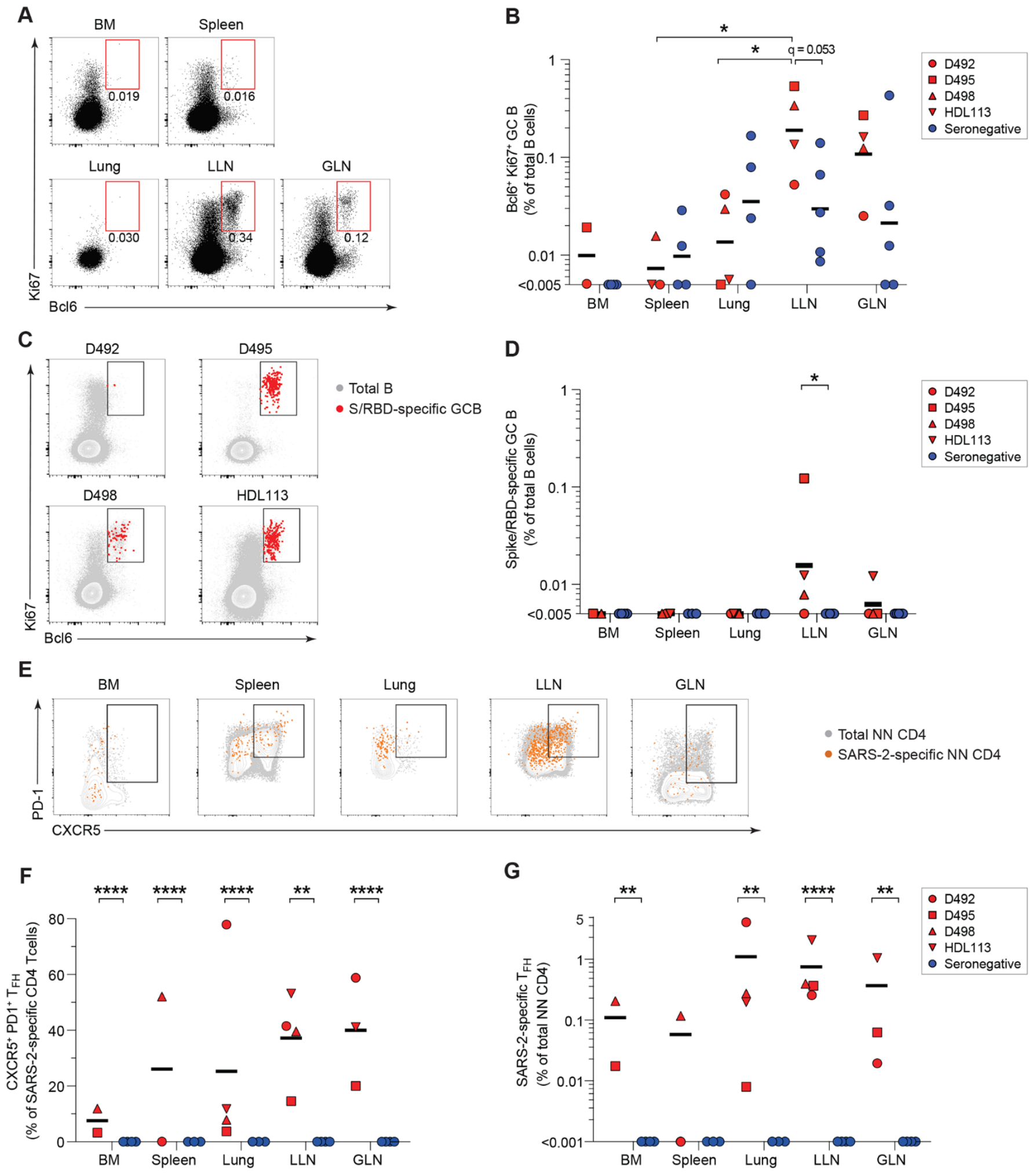
Fig. 5. SARS-CoV-2-specific germinal center B cells and follicular helper T cells in seropositive donors. (A) Bcl6 ${ }^{+} \mathrm{Ki} 67^{+}$germinal center (GC) B cells in different tissues, shown in representative flow cytometry plots from seropositive donor D498 (see fig. S5 for gating). (B) Frequency of Bcl6 $\mathrm{Ki}^{6} 7^{+} \mathrm{GC}$ B cells in tissue sites of seropositive and seronegative donors expressed as a percentage of total $C D 19^{+} \mathrm{CD} 2 \mathrm{O}^{+}$total $B$ cells. (C) GC B cells in the LLN for each donor shown in representative flow cytometry plots. GC B cells specific to S/RBD are depicted in red. (D) Frequency of S/RBD-specific GC B cells as a percentage of total B cells. (E) $T_{F H}$ phenotype and frequency among NN CD4 ${ }^{+} \mathrm{T}$ cells per tissue as depicted by the rectangle gate, shown in representative flow cytometry plots from seropositive donor D498 (lung, LLN, spleen, BM) and D495 (GLN); see Materials and Methods for gating strategy. SARS-CoV-2-specific NN CD4 ${ }^{+} \mathrm{T}$ cells are highlighted in orange. (F) Frequency of CXCR5 ${ }^{+} P D-1^{+} T_{F H}$ cells per tissue as percentage of SARS-CoV-2-specific CD4 ${ }^{+} T$ cells. (G) Frequency of SARSCoV-2-specific $T_{F H}$ cells per tissue as percentage of total NN CD4 ${ }^{+}$T cells. Statistical analysis was performed on log-transformed datasets using one-way ANOVA, corrected for multiple comparisons by FDR using two-stage linear step-up procedure of Benjamini, Krieger, and Yekutieli. * $\mathrm{q} \leq 0.05$, ${ }^{*} \mathrm{q} \leq 0.01$; ${ }^{* * *} \mathrm{q} \leq 0.0001$. SARS-2, SARS-CoV-2; S/RBD, SARS-CoV-2 Spike and/or RBD; GC, germinal center; BM, bone marrow; LLN, lungassociated lymph node; GLN, gut-associated lymph node; NN, non-naïve; Follicular helper T cell, $\mathrm{T}_{\mathrm{FH}}$. 
A

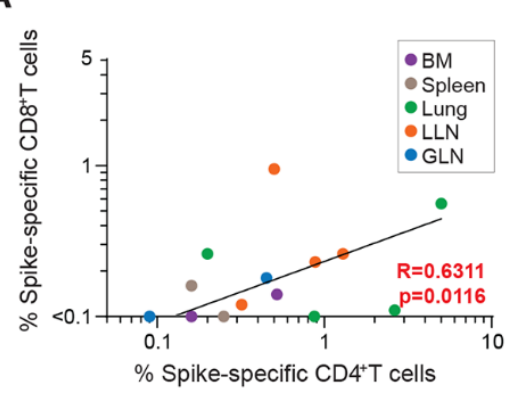

D

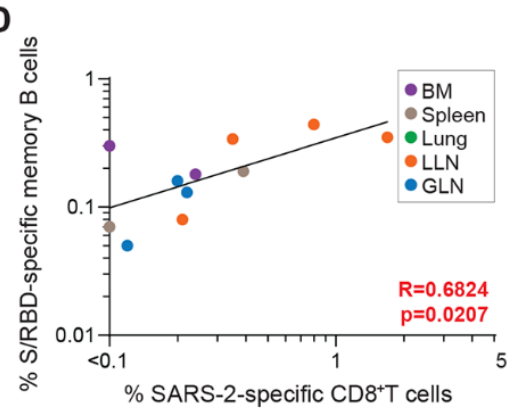

B

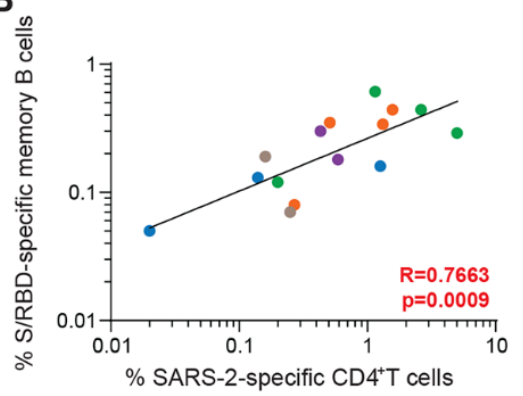

$\mathbf{E}$

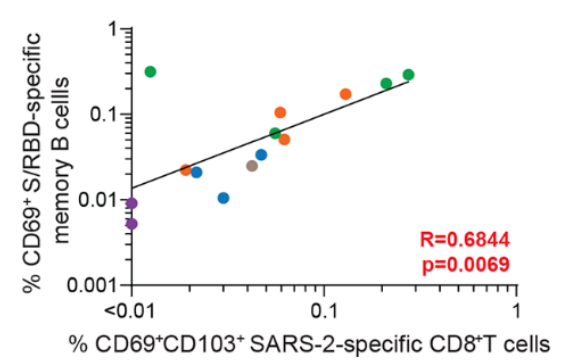

C

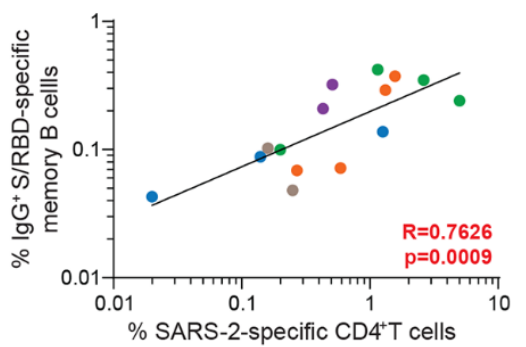

$\mathbf{F}$

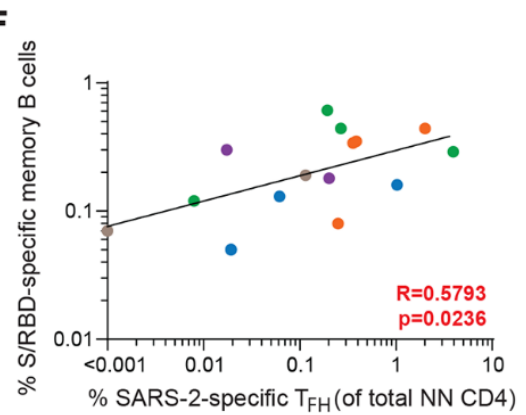

G

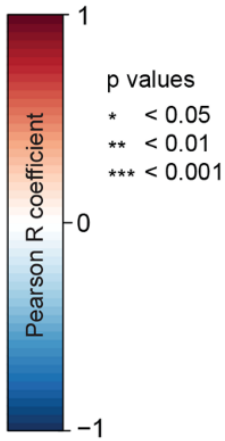

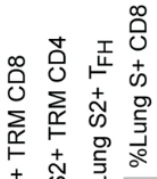

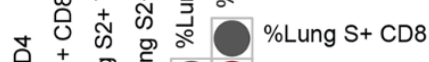

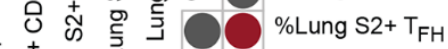

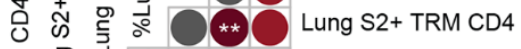

至

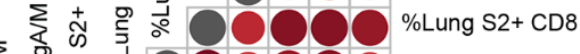

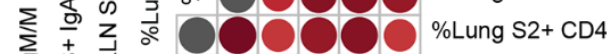

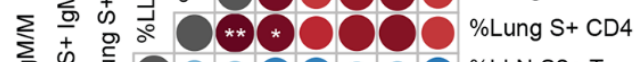

$\sum_{\text {i g }}$ क

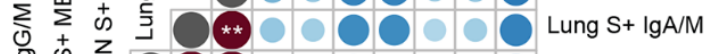

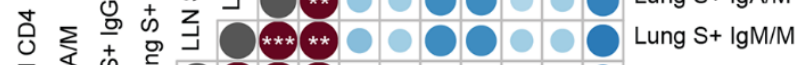

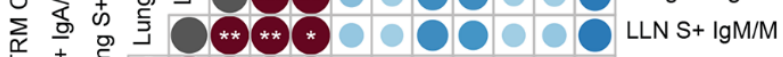

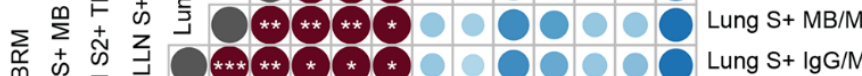

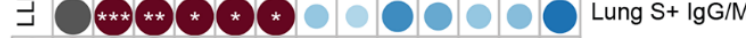

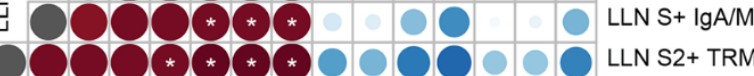

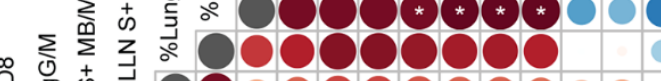

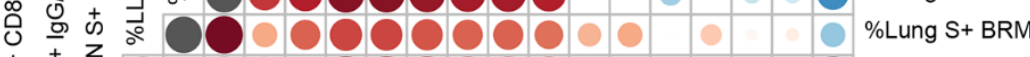
t

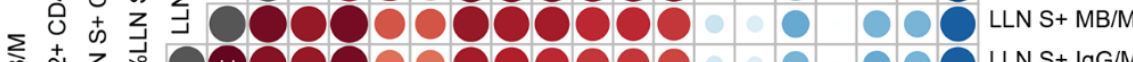

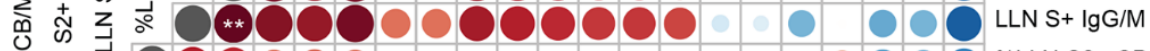

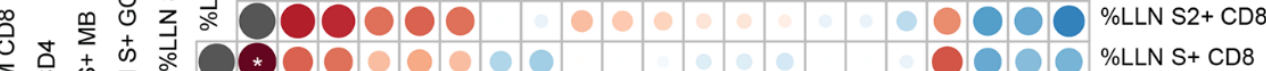

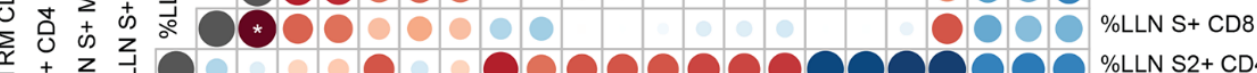

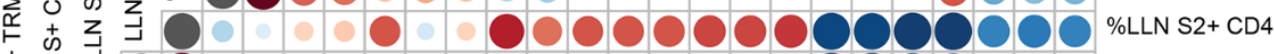
苋z 。้

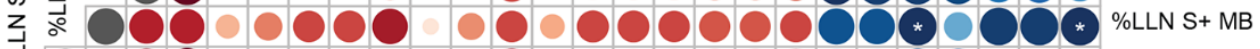

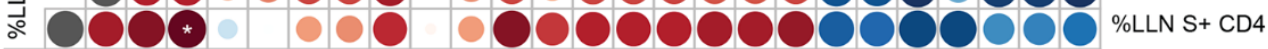
$0000000000000000000000 \%$ LLLN S2+ TRM CD8 
Fig. 6. SARS-CoV-2-specific immune memory relationships across organs. (A) Correlation between SARSCoV-2 Spike-specific CD4 ${ }^{+} T$ cells as frequency of total CD4 ${ }^{+} T$ cells and Spike-specific CD8 ${ }^{+} T$ cells as frequency of total CD8 ${ }^{+} T$ cells. (B) Correlation between the frequency of SARS-CoV-2-specific CD4 ${ }^{+} \mathrm{T}$ cells and SARS-CoV2 S/RBD-specific memory B cells. (C) Correlation between SARS-CoV-2-specific CD4 ${ }^{+} \mathrm{T}^{-}$cells and IgG ${ }^{+}$SARSCoV-2 S/RBD-specific memory B cells. (D) Correlation between SARS-CoV-2-specific CD8 ${ }^{+}$T cells and SARSCoV-2 S/RBD-specific memory B cells within lymphoid tissues. (E) Correlation between SARS-CoV-2-specific $\mathrm{CD}^{2}{ }^{+} \mathrm{CD} 103^{+} \mathrm{CD}^{+}$TRM cells and CD69+ SARS-CoV-2 S/RBD-specific BRM. (F) Correlation between SARSCoV-2-specific PD- $1^{+}$CXCR5 ${ }^{+} T_{F H}$ cells as frequency of NN CD4 ${ }^{+}$T cells and SARS-CoV-2 S/RBD-specific memory $B$ cells as frequency of total memory B cells. (G) Correlogram of SARS-CoV-2-specific lung and LLN lymphocyte populations. Pearson R coefficients are shown from blue (-1.0) to red (1.0); R values are indicated by color and circle size. SARS-CoV-2-specific lymphocyte frequencies are depicted as a percentage of the parent population (\%) or as counts per million PBMCs (/M); SARS-CoV-2-specific $\mathrm{T}_{\mathrm{FH}}$ cells are a percentage of total NN CD4+ ${ }^{+}$ cells. Statistical analysis was performed on datasets using Pearson correlation. ${ }^{*}, p \leq 0.05 ;{ }^{* *}, p \leq 0.01 ;{ }^{* *}, p \leq$ 0.001. SARS-2, SARS-CoV-2; S/RBD, SARS-CoV-2 Spike and/or RBD; BM, bone marrow; LLN, lung-associated lymph node; GLN, gut-associated lymph node; $T_{F H}$, follicular helper T cell; GCB, germinal center B cell; MB, memory B cell; TRM, CD69+CD103+ resident memory T cell; BRM, CD69+ resident memory B cell; S+, Spikeprotein-specific; S2+, SARS-CoV-2-specific. 